Linköping University Medical Dissertations No. 1503

\title{
Towards safer care in Sweden? Studies of influences on patient safety
}

\author{
Mikaela Ridelberg
}

1.UU UNKKDENG

Department of Medical and Health Sciences

Linköping University, Sweden

Linköping 2016 
(c) Mikaela Ridelberg, 2016

Published article has been reprinted with the permission of the copyright holder.

Printed in Sweden by LiU-Tryck, Linköping, Sweden, 2016

ISBN 978-91-7685-857-8

ISSN $0345-0082$ 
Better to be safe than sorry!

English proverb 



\section{CONTENTS}

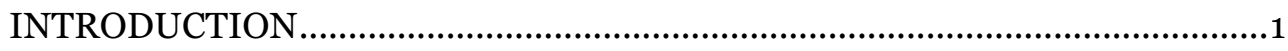

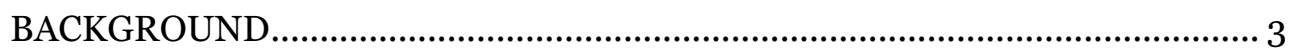

What is patient safety? ................................................................................... 3

Understanding adverse events..................................................................... 4

Patient safety research and policies........................................................... 6

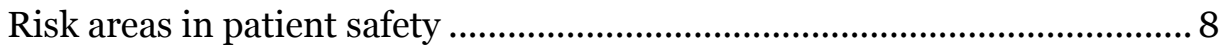

Health care-associated infections ................................................................ 8

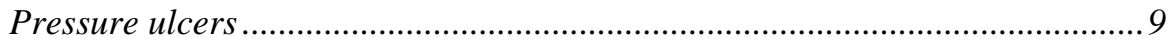

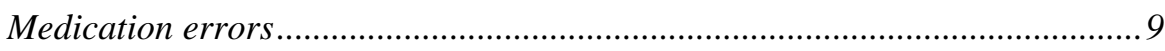

Safe surgery ....................................................................................... 10

Patient safety activities and actors in Sweden............................................... 10

THEORETICAL FRAMEWORK.......................................................................15

Use of theory in the thesis .................................................................................15

Donabedian's triad (structure, process and outcomes) and context ............16

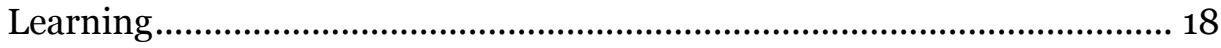

From data to organizational learning.......................................................... 18

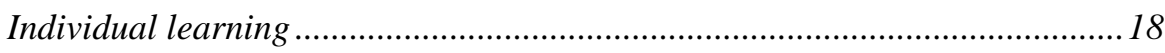

Organizational learning …………………………….............................. 19

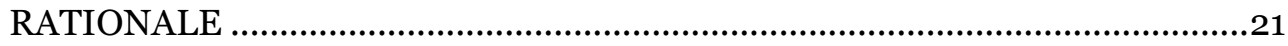

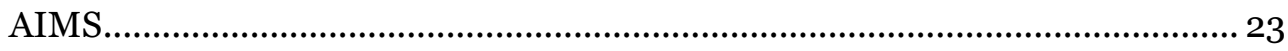

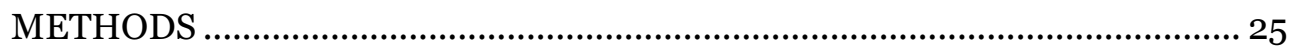

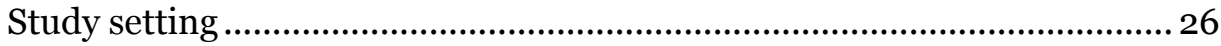

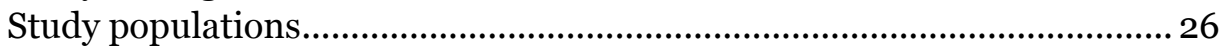

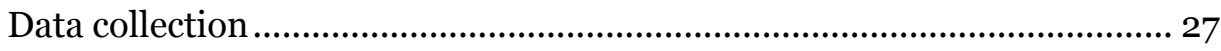

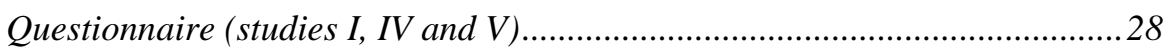

Interview guide (studies II and III).............................................................29

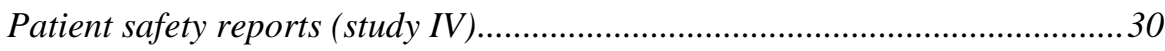

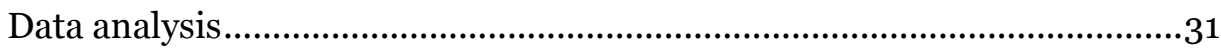

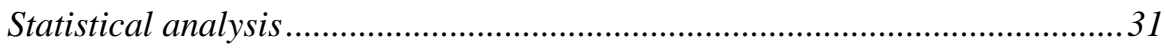

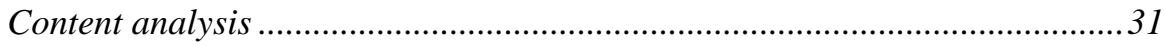


Ethical considerations............................................................................... 33

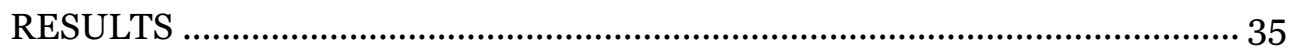

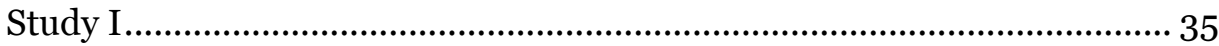

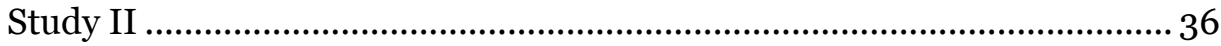

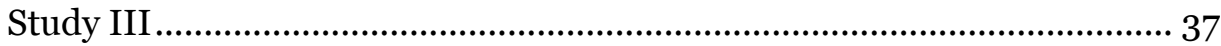

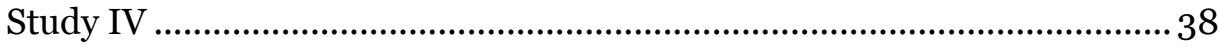

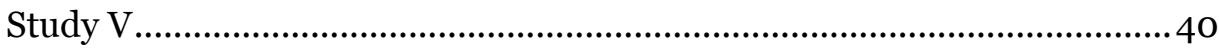

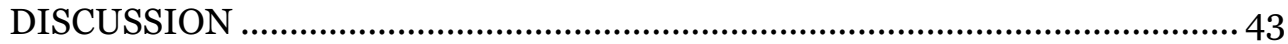

A framework for understanding and explaining influences on patient

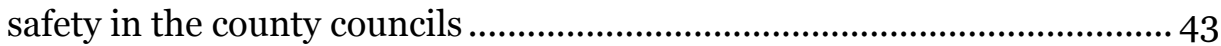

Potentially important areas for safer care in Sweden ................................... 44

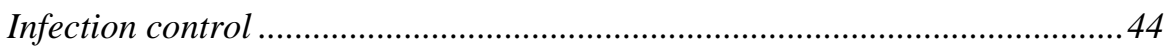

Learning from errors .................................................................................... 46

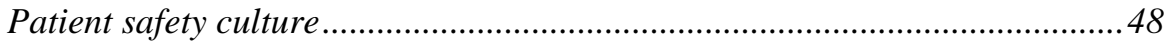



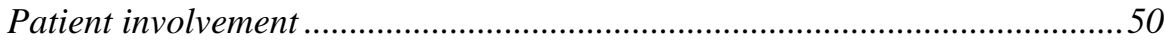

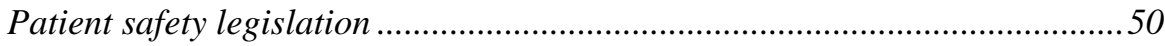

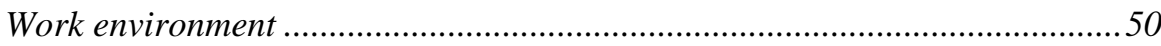

Multiple influences on patient safety ............................................................51

Methodological considerations ..................................................................... 52

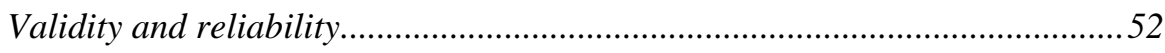

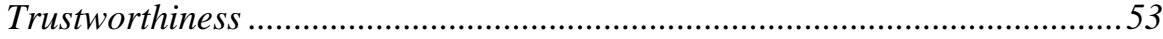

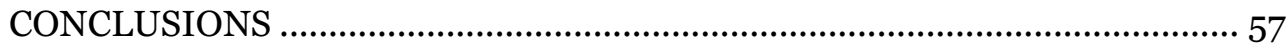

IMPLICATIONS AND FUTURE RESEARCH ………………......................... 59



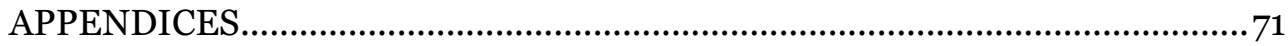




\section{ABSTRACT}

Patient safety has progressed in 15 years from being a relatively insignificant issue to a position high on the agenda for health care providers, managers and policy-makers as well as the general public. Sweden has seen increased national, regional and local patient safety efforts since 2011 when a new patient safety law was introduced and a four-year financial incentive plan was launched to encourage county councils to carry out specified measures and meet certain patient safety related criteria. However, little is known about what structures and processes contribute to improved patient safety outcomes and how the context influences the results.

The overall aim of this thesis was to generate knowledge for improved understanding and explanation of influences on patient safety in the county councils in Sweden. To address this issue, five studies were conducted: interviews with nurses and infection control practitioners, surveys to patient safety officers and a document analysis of patient safety reports. Patient safety officers are healthcare professionals who hold key positions in their county council's patient safety work. The findings from the studies were structured through a framework based on Donabedian's triad (with a contextual element added) and applying a learning perspective, highlight areas that are potentially important to improve the patient safety in Swedish county councils.

Study I showed that the conditions for the county councils' patient safety work could be improved. Conducting root-cause analysis and attaining an organizational culture that encourages reporting and avoids blame were perceived to be of importance for improving patient safety. Study II showed that nurses perceived facilitators and barriers for improved patient safety at several system levels. Study III revealed many different types of obstacles to effective surveillance of health care-associated infections (HAIs), the majority belonging to the early stages of the surveillance process. Many of the obstacles described by the infection control practitioners restricted the use of results in efforts to reduce HAIs. Study IV of the Patient Safety Reports identified 14 different structure elements of patient safety work, 31 process elements and 23 outcome elements. These reports were perceived by patient safety officers to be useful for providing a structure for patient safety work in the county councils, for enhancing the focus on patient safety issues and for learning from the patient safety work that is undertaken. In Study V the patient safety officers rated ef- 
forts to reduce the use of antibiotics and improved communication between health care practitioners and patients as most important for attaining current and future levels of patient safety in their county council. The patient safety officers also perceived that the most successful county councils regarding patient safety have good leadership support, a longterm commitment and a functional work organisation for patient safety work.

Taken together, the five studies of this thesis demonstrate that patient safety is a multifaceted problem that requires multifaceted solutions. The findings point to an insufficient transition of assembled data and information into action and learning for improved patient safety. 


\section{SVENSK SAMMANFATTNING}

Patientsäkerhet har under de senaste 15 åren utvecklats från att vara ett mindre uppmärksammat problem till att bli en högt prioriterad fråga för hälso- och sjukvårdens medarbetare och chefer, forskare, beslutsfattare och allmänheten. Arbete för ökad patientsäkerhet i Sverige har intensifierats sedan 2011, då en ny patientsäkerhetslag infördes och en fyrårig överenskommelse för förbättrad patientsäkerhet slöts mellan Sveriges Kommuner och Landsting (SKL) och den svenska regeringen i syfte att finansiellt stimulera landsting/regioner att utföra vissa aktiviteter och uppnå specifika resultat. Trots dessa satsningar på patientsäkerhet saknas mycket kunskap om vilka strukturer och processer som kan bidra till ökad patientsäkerhet och hur kontexten påverkar olika patientsäkerhetsutfall.

Avhandlingens övergripande syfte var att generera kunskap för förbättrad förståelse och förklaring av faktorer av betydelse för patientsäkerheten i landstingen/regionerna i Sverige. Fem studier har genomförts: två intervjustudier med sjuksköterskor och personer ansvariga för punktprevalensmätningarna av vårdrelaterade infektioner i sina respektive landsting/regioner, två enkätundersökningar till patientsäkerhetsexperter och en dokumentanalys av patientsäkerhetsberättelser. Patientsäkerhetsexperter är hälso- och sjukvårdspersonal som har insikt i, kunskap om och kan påverka beslut beträffande patientsäkerhet i respektive landsting/region, samt med inflytande över det patientsäkerhetsarbete som bedrivs i landstingen/regionerna. Resultaten från studierna diskuteras med utgångspunkt från ett ramverk, den så kallade Donabedians triad (kompletterad med kontext), och ur ett lärandeperspektiv. Resultaten pekar på flera områden av betydelse för förbättrad patientsäkerhet i de svenska landstingen/regionerna.

Studie I visade att förutsättningarna för landstingens patientsäkerhetsarbete skulle kunna förbättras. Genomförande av händelseanalyser och en förbättrad organisationskultur som uppmuntrar till rapportering och undviker skuldbeläggning uppfattas vara av stor betydelse för ökad patientsäkerhet. Av Studie II framgick att sjuksköterskor identifierade underlättande och försvårande faktorer för ökad patientsäkerhet på flera nivåer i organisationen. Studie III undersökte vilka hinder som finns vid processen att övervaka och mäta vårdrelaterade infektioner. Resultaten visade på många hinder för denna process, varav en majoritet återfanns $\mathrm{i}$ 
de tidiga stegen av processen. Studie IV byggde på en analys av de patientsäkerhetsberättelser landstingen/regionerna sammanställer varje år för att beskriva sitt arbete med patientsäkerhet. Av studien framkom att berättelserna redovisade 14 olika struktur-, 31 process- och 23 resultatvariabler. Berättelserna ansågs av patientsäkerhetsexperter vara till nytta för att ge patientsäkerhetsarbetet struktur, för att få ett ökat fokus på patientsäkerhetsfrågor och för att lära från patientsäkerhetsarbetet som bedrivs. I studie $\mathrm{V}$ angav patientsäkerhetsexperter insatser för att minska användningen av antibiotika och förbättrad kommunikation mellan sjukvårdspersonal och patienter som viktigast för att uppnå dagens nivå av patientsäkerhet och för att åstadkomma ökad patientsäkerhet i framtiden. Patientsäkerhetsexperterna uppfattade också att de mest framgångsrika landstingen/regionerna är de som har ett bra ledningsstöd, ett långsiktigt engagemang och ett väl organiserat patientsäkerhetsarbete.

Sammantaget visar avhandlingens fem studier att patientsäkerhet är ett mångfacetterat problem som kräver mångfacetterade lösningar. Ett återkommande fynd är ett otillräckligt nyttiggörande av patientsäkerhetsrelaterade data och information i form av handling och lärande för förbättrad patientsäkerhet. 


\section{LIST OF PAPERS}

I. Mikaela Nygren, Kerstin Roback, Annica Öhrn, Hans Rutberg, Mikael Rahmqvist and Per Nilsen. Factors influencing patient safety in Sweden: perceptions of patient safety officers in the county councils. BMC Health Services Research, 2013, Vol. 13, 52.

II. Mikaela Ridelberg, Kerstin Roback and Per Nilsen. Facilitators and barriers influencing patient safety in Swedish hospitals: a qualitative study of nurses' perceptions. BMC Nursing, 2014, Vol.13 (23).

III. Mikaela Ridelberg and Per Nilsen. Using surveillance data to reduce healthcare-associated infection: a qualitative study in Sweden. Journal of Infection Prevention, 2015, Vol.16 (5): 208-214.

IV. Mikaela Ridelberg, Kerstin Roback, Per Nilsen and Siw Carlfjord. Patient safety work in Sweden: quantitative and qualitative analysis of annual patient safety reports. Submitted.

V. Mikaela Ridelberg, Kerstin Roback and Per Nilsen. How can safer care be achieved? Patient safety officers' perceptions of factors influencing patient safety in Sweden. Journal of Patient Safety. Accepted 5 October 2015. 



\section{ACKNOWLEDGEMENTS}

I have always liked to improve whatever I am working on, and as a nurse working with patient safety issues, the reply did not take much consideration when I was offered the opportunity to pursue doctoral studies in this area. However, it is not always as easy to be a $\mathrm{PhD}$ candidate as it was to say Yes to the position. Maybe that is why I have combined my studies with a lot of other stuff (i.e. got married; got a dog; got pregnant; moved; had baby; moved again), during this 5-year period of my life. And maybe that is also why my colleagues know more about my private life than about what I have written in this thesis. Many people, whether they are aware of it or not, have supported and helped me through these years of studies and in the making of this thesis, and therefore I would like to give my sincere thanks to all of you!

First and foremost, I want to thank my main supervisor Per Nilsen for the infectious enthusiasm in doing research, all the nicely packaged and tactful criticisms, smart comments and incredible writing skills. Without Per I do not know how many studies would have been completed or even started? Thank you also for all the discussions about music, movies and common places of residence (i.e. Lomvägen and Kungsholmen). Thank you Kerstin Roback, my co-supervisor, for your generous support and for always contributing with a critical eye and sharp logic, but above all thank you for a warm friendship.

I know for sure that the studies would never been written or even commenced without the patient safety officers, infection control practitioners and nurses who participated in the studies. Thank you for sharing your wisdom about the patient safety issues in your daily work! The studies in this thesis would also not have been possible without the contribution and support of my intelligent co-writers: Hans Rutberg, Annica Öhrn, Mikael Rahmqvist and Siw Carlfjord! Thanks to Eva Estling, Petra Hasselqvist and Einar Sjögren at SALAR (SKL) for support, critical views and encouragement. Also, huge thanks to Ann-Christine Karell for your contribution with interviews and planning in study III.

Special thanks to all the intelligent people who I have had the pleasure to meet and who have reviewed my dissertation work at different phases; Synnevö Ödegård, an inspiration and role model in the patient safety field 
as the first PhD in patient safety in Sweden, who had the "pleasure" to review my "half-time progress" together with Johan Sanne. Thank you both for your helpful input. In my later thesis-writing phase I also had the fortune to have my work reviewed by Barbro Krevers, Janna Skagerström and Mita Danielsson. Thank you for your inputs and support, which gave me the energy to put in the final effort to complete this thesis. Special thanks Janna Skagerström, not only for scrutinizing my thesis, but foremost always being there as a friend! We have spoken more about life than about the doctoral studies and our shared main supervisor, but the few discussions we have had, have been essential.

Spending time with my wonderful colleagues at the Department of Healthcare Analysis has always left me energized and happy, and I sure miss the fika and lunch breaks with you! Special thanks to Lars and Mattias, my golf lunch-friends for life! Also a special thanks to Lena Hector, not only for giving me all the answers to my never-ending tiresome questions regarding administrative issues, but always having your door open for a chat, some chats more sincere than others.

Thank you all board members in Domfil 2013-14. I have learned so much by hanging out and "working" with you. The time on the board has been essential in my doctoral studies.

My family, old and new; mum and dad, my step-mum, my sister and brothers and sisters-in-law; all my friends (ingen nämnd, ingen glömd): your love has carried me through the whole period of doctoral studies. Thank you for being in my life!

Thank you my love Filip! Thank you for always supporting and believing in me in every way. I would not have been able to finish this work without your support. Thank you Pauline for being the best person in the world! Thank you Albert for always bringing joy and support in paper shredding!

Linköping in February 2016

\section{Mikaela Ridelberg}




\section{INTRODUCTION}

Patient safety is an important issue of interest to most people. In various media, we can read, see or hear about patient safety problems almost on a daily basis. And as long as there is, and has been, health care, achieving safe care will be a challenge that must be addressed because safe care does not miraculously happen by itself. This thesis does not provide conclusive answers to the patient safety challenge, but it attempts to provide insights into some aspects of the issue.

Patient safety has long been recognized as an area for improvement. However, it was not until the turn of the millennium that things started to happen in the patient safety policymaking and research area. The publication of the Institute of Medicine report To Err Is Human (Kohn et al. 2000) is generally considered a crucial event in the history of patient safety. It attracted a great deal of attention and led to increased awareness of the magnitude of the patient safety problem. The report addressed the patient safety problem in the United States, making the startling observation that the number of deaths caused by unsafe care was equivalent to a jumbo jet (i.e. a Boeing 747) full of passengers crashing every day. The report did not merely report on the problem but also pointed to what needed to be done in health care in order to improve patient safety. The report included a number of calls for implementation of structural, contextual and process-oriented changes in health care. It provided the impetus for a significantly increased investment in research and development and stronger emphasis on policymaking in patient safety (Kohn et al. 2000).

Still, it is important to emphasize that the Institute of Medicine report by no means was the first investigation into patient safety. In fact, there had been many studies before the millennium, some of which To Err Is $\mathrm{Hu}$ man built on. The most well-known study is the Harvard Medical Practice Study in the late 1980s (Brennan et al. 1991), which provided a new standard on how to measures the incidence of adverse events (Baker et al. 2004). Several other international studies in the 1990 s showed the magnitude of the problem of unsafe health care (Wilson et al. 1995; Schiøler et al. 2001; Davis et al. 2002). 
Patient safety was also on the research, development and policymaking agenda in Sweden well before To Err Is Human was published, yet it was not until the mid-200os that more concerted efforts by national authorities and agencies were instigated. Important efforts have been launched by the Swedish Association of Local Authorities and Regions (SALAR) and the National Board of Health and Welfare. A study by Soop et al. (2009) showed that $8.6 \%$ of patients cared for in Swedish general hospitals were subject to adverse events. The study received wide attention in Sweden because it indicated that the problem was as profound in Sweden as in other countries. This prompted SALAR to produce guidelines to prevent falls, pressure ulcers, medication errors in care transitions and health care-associated infections (HAIs) (SOU 2008).

The Swedish effort to achieve improved patient safety was further intensified in 2011. A new patient safety law (SFS 2010:659) was introduced and an agreement was reached between the Swedish government and SALAR concerning a performance-based financial incentive plan to encourage county councils to carry out certain tasks and achieve specific results regarding patient safety during the years 2011-2014. A "zero vision", inspired by the highly successful Swedish traffic safety concept, has been discussed for adverse events in health care although it has not been officially formalized (SOU 2008).

The high ambition to improve patient safety in Sweden naturally begs the question of how this can be achieved. After all, research concerning patient safety is a relatively new field and there is not extensive or conclusive knowledge about the processes and structures most likely to advance patient safety (Pronovost et al. 2006). Not all interventions for improved patient safety can be isolated and studied under controlled research conditions. Patient safety is integrated into everyday real-world health care practice, making this moving target a challenging study object. As a result, patient safety tends to be experience-based or expert-based rather than evidence-based even though the knowledge and evidence base is expanding (Shekelle et al. 2011; Goeschel et al. 2010). These challenges make it important to understand what the perceptions and practices concerning patient safety in Swedish county councils are. This thesis is aimed at generating knowledge and explanation of influences on patient safety in the county councils in Sweden. 


\section{BACKGROUND}

This section provides an introduction to the area of patient safety. The chapter begins with definitions and discussions concerning the key concepts of patient safety and adverse events. The development of patient safety research is outlined and some of the important patient safety activities and actors in a Swedish context are described.

\section{What is patient safety?}

Patient safety has been defined in numerous ways by researchers, policymakers and practitioners. Hence, there is a lack of consensus regarding the precise meaning of the concept although most definitions share some characteristics.

According to Swedish law (SFS 2010:659), patient safety is the "protection against adverse events", or "protection against health care damage", using a direct translation of the Swedish term "vårdskada". The Swedish word for adverse event incorporates the fact that the damage is caused by the health care. The Swedish law also defines adverse events as the "suffering, bodily or mental harm or illness and deaths that could have been avoided if adequate measures had been taken at the patient contact with the health care system". This definition points out that adverse events could be avoided if adequate measures have been taken.

The World Health Organization (2013) offers a similar definition: "Patient safety is the prevention of errors and adverse effect to patients associated with health care". This definition does not say anything about preventability as the one above; neither does it define "errors and adverse effects".

A more elaborative definition is provided by the Agency for Healthcare Research \& Quality's (AHQR) glossary (2013): "Freedom from accidental or preventable injuries produced by medical care. Thus, practices or interventions that improve patient safety are those that reduce the occurrence of preventable adverse events." AHQR also defines adverse event: "Any injury caused by medical care" and further explaining that identifying something as an adverse event does not imply "error", "negligence", or "poor quality care"; it simply indicates that an undesirable clinical out- 
come resulted from some aspect of diagnosis or therapy, rather than from an underlying disease process. AHQR goes beyond the typical lexical definition and gives specific examples as to what an adverse event could be. The shorter Swedish and WHO definitions implicitly also chase a "zeroadverse events vision".

The Institute of Medicine (2000) defines patient safety as "the avoidance, prevention and amelioration of adverse outcomes or injuries stemming from the process of healthcare". This definition captures several layers of mitigation of harm to patients. It also points to the importance of the process of health care.

Common to all definitions of patient safety is that this is something that is concerned with protection or freedom from harm or injury. Hence, definitions of safety tend to say more about what comprises "unsafety" than about the substantive properties of "safety" itself. For instance, the Merriam-Webster Dictionary defines safety as "the condition of being safe from undergoing or causing hurt, injury, or loss". Risk has traditionally been defined as the "inverse" of safety (Melinder 2000). Thus, the greater the risk, the lesser the safety, and vice versa.

\section{Understanding adverse events}

An adverse event is an injury that was caused by health care, for example a pressure ulcer or an HAI. The occurrence of an adverse event can be understood from several perspectives: clinical, sociological, psychological, quality improvement, technological and so forth (Walshe and Boaden 2006). The most commonly applied perspective in patient safety research today is the systems perspective, with James Reason (2000) as one of the most prominent researchers and theorists.

The so-called Swiss cheese model (Figure 1) by Reason (2000) describes how adverse events can occur despite several "protective layers" (slices of cheese) due to "holes" (in the cheese) in these layers. The cheese slices can be seen as representing barriers at different levels: the system level, organizational level, workplace level and the frontline staff level. The holes in these barriers consist of two kinds of failures: active failures in the frontline and latent conditions in the system. Active failures are the unsafe acts (slips, mistakes, and even violations) by the person(s) in contact with the patient or the system. Latent conditions are the factors that can contribute to an error, but may lay dormant for a long period of time. All 
strategic decisions (such as new building plans, policies, and procedures) made in the health care system may cause a latent condition at the workplace. Examples of latent conditions are understaffing, inexperienced staff and untrustworthy alarms at the workplace (Reason 2000). The model implies that it is difficult to predict the consequences of changes in one aspect or layer of a complex organization such as health care (Rollenhagen 2013).

Figure 1. Reason's cheese model. Adapted from Reason (2000).

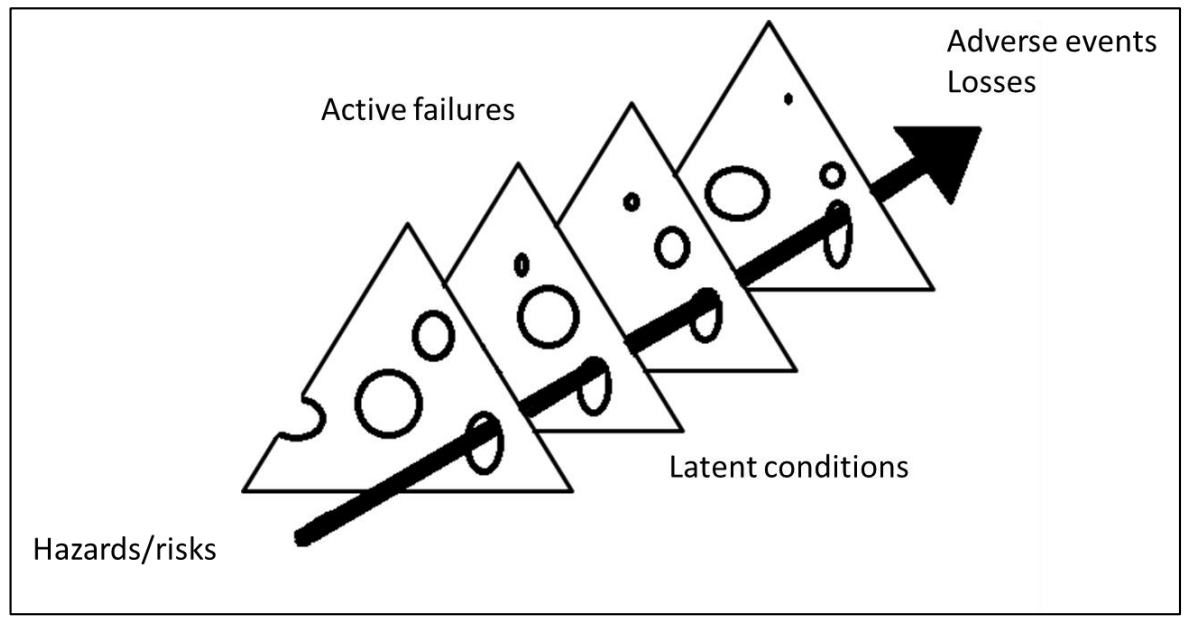

Charles Vincent is another influential patient safety researcher representing the system perspective. He has developed a taxonomy of different types of factors that cause errors in health care, by way of adapting and extending Reason's Swiss cheese model (Vincent et al. 1998). The seven levels of factors that contribute to and influence safety are: patient factors; task factors; individual factors; team factors; working conditions; organizational factors; and institutional factors (Vincent et al. 1998).

Reason (2004) stresses that the frontline of health care is the last barrier before an error occurs, therefore requiring special attention. Still, research conducted from a system perspective has been critiqued for placing too much emphasis on organizational (system) faults and for focusing on "why has it gone wrong". The system perspective does not consider human beings as "heroes" in the system and does not explain "why things go right". It has been argued that a shift of focus to understand why something goes right (most of the time) would make patient safety initiatives more proactive, rather than reactive. This perspective is also referred to as resilience science (Nemeth et al. 2008) and has been labelled "Patient 
Safety II" by Rollenhagen (with reactive patient safety being "Patient Safety I") (Rollenhagen 2013). This perspective does not mean that the focus has returned to the individual (with a "blame and shame" attitude), but rather explores what can be learnt from the heroes that contribute to successful outcomes in critical situations where an accident (adverse event) was about to happen but did not.

\section{Patient safety research and policies}

The Harvard Medical Practice Study in the late 1980s was the first scientific study that investigated the magnitude of the problem of patients being harmed in health care organizations by using medical record reviews. This report provided a new standard of how to measure the incidence of adverse events (Baker et al. 2004; Brennan et al. 1991). The report brought attention to the issue for research and policy discussions in several countries. However, it was not until the aforementioned Institute of Medicine report, To Err Is Human, was published in 2000 that patient safety research really took off. This is evident from Figure 2, which shows the percentage of all published abstracts in the research database PubMed that include the search term "patient safety". The figure shows a steep increase in the last 15 years.

Figure 2. Percentage of all published abstract in PubMed with searchword "Patient Safety".

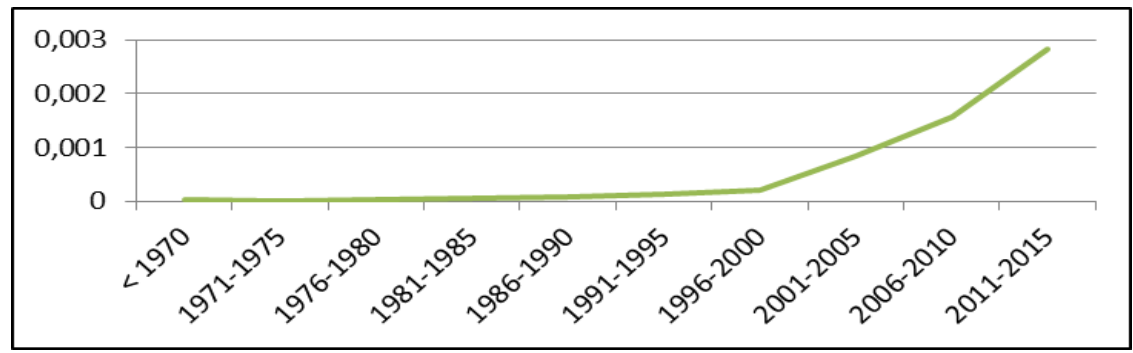

The Institute of Medicine's report was critically important in raising awareness of the patient safety problem, both in the United States and internationally. The report led to increased research funding for patient safety issues and a rapid expansion of research. The report also inspired initiatives to address patient safety problems in many countries and internationally. Details of some of the key initiatives undertaken are provided in Table 1. 







\section{Risk areas in patient safety}

Patient safety is often described in terms of a number of specific risk areas, i.e. activities or processes in health care that cause more adverse events or are considered more risky than others. Retrospective record review can be used to detect risk areas in health care (Schildmeijer 2013). The first study using this method was the Harvard medical study (Leape et al. 1991). The authors as well as prompting the systemic perspective on errors instead of the individual blame perspective also showed that errors in medical practice are common (Leape et al. 1991; Brennan et al. 1991). Most common errors were management errors, errors due to aseptic precautions at operations, drug-related adverse events and error among the large group of elderly patients. A similar study in Sweden (Soop et al. 2009) showed that surgical (invasive) procedures and medications errors are most common.

The Institute of Medicine report (Kohn et al. 2000) also highlighted medication errors, surgical errors, preventable suicides, HAIs, falls, burns, pressure ulcers and mistaken identity as common errors. The financial incentive plan for improved patient safety in 2011-2014 in Sweden (Appendix A) emphasized the importance of four areas: HAIs, pressure ulcers, medication errors and patient safety culture.

\section{Health care-associated infections}

HAIs are defined by the World Health Organization (2011, p. 6) as: "An infection occurring in a patient during the process of care in a hospital or other health-care facility which was not present or incubating at the time of admission. This includes infections acquired in the hospital, but appearing after discharge, and also occupational infections among staff of the facility." These infections pose a substantial problem in all areas of health care, including long-term care facilities (Eriksen et al. 2007; Moro et al. 2007) and hospital settings (Gravel et al. 2007; Hajdu et al. 2007; Llata et al. 2009; van der Kooi et al. 2010; Eriksen et al. 2005; Lyytikäinen et al. 2008; Izquierdo-Cubas et al. 2008).

The problem of health care infections is multifaceted and several strategies have targeted the problem. The most commonly used strategy is in- 
terventions that promote better hand hygiene (Griffin 2007; Yokoe et al. 2014) and surveillance (Griffin 2007; Yokoe et al. 2014). Other interventions are decontamination of the environment and equipment, contact precautions for infected and colonized patients, and device bundles (central line bundle and ventilator bundle) (Griffin 2007). There have also been calls for involving the patients and relatives in improving hand hygiene when they receive care or visit care facilities (Pittet et al. 2011; World Health Organization 2011). Surveillance can be used to identify appropriate priority areas and assess the impact of interventions (World Health Organization 2011). There are some challenges when it comes to the surveillance of HAIs such as the need for a conventional definition of the infections, the efforts in time and cost for collecting data etc. (World Health Organization 2011). In Sweden and many other countries, national surveillance of HAIs is performed with point prevalence surveys (Emmerson et al. 1996; Eriksen et al. 2005; Humphreys et al. 2008; Lyytikäinen et al. 2008; Van der Kooi et al. 2010).

\section{Pressure ulcers}

More than one in six hospital patients in Sweden and many other European countries experience pressure ulcers (Vanderwee et al. 2007; Bredesen et al. 2015; Bååth et al. 2014). The proportion is slightly lower in nursing homes in Sweden (Bååth et al. 2014). The severe and persistent pain that comes from pressure ulcers affects the patient both physically, mentally, emotionally and socially (Gorecki et al. 2014).

Interventions for preventing and healing pressure ulcers are multimodal. The most widely used interventions include risk assessments, nutritional interventions, pressure relieving and distributing materials and turning schemes (Bååth et al. 2014). In Sweden, pressure ulcer prevalence is measured using point prevalence surveys (Vanderwee et al. 2007).

\section{Medication errors}

Almost all hospitalized patients in hospital take medication, prescribed or non-prescribed and the patients themselves can also self-medicate. There is much room for errors when it comes to medication in health care: from the prescription, to the preparation, to delivering the medication to the patient and when the patient receives/takes the medication. The Institute of Medicine (1999) believes that medication errors are often preventable, 
although it will require multiple interventions to reduce the error rate significantly. And one must not forget that patients make errors too.

Zwicker and Fulmer (2012) recommend several different strategies to decrease medication errors. Strategies and tools to establish if there is a risk for errors and different interventions during the hospital stay are recommended, e.g. patient empowerment, prescribing principles and education to both patients and caregivers. In addition, a few interventions at discharge and follow-up are recommended.

\section{Safe surgery}

Surgery can be life-saving but it can also cause a lot of harm. Adverse events occur in $14.4 \%$ of surgical patients and of these adverse events $14 \%$ have fatal or severe consequences (Anderson et al. 2013).

Safe surgery involves the following areas: surgical site infection prevention; safe anaesthesia; safe surgical teams; and measurement of surgical services where there is a lack of basic data (World Health Organization 2008). A widespread tool for safer surgery is the WHO's Safe Surgery checklist, an instrument that has been shown to reduce rates of death and complications among patients after surgery (Haynes et al. 2009). The checklist has been widely implemented internationally and is considered to be an evidence-based tool for safer surgery (Haynes et al. 2009; The Joint Commission 2012; Russ et al. 2015).

\section{Patient safety activities and actors in Sweden}

Although patient safety initiatives have been intensified in recent years, issues concerning the safety of health care have been discussed in Sweden for many years. Three incidents in Swedish health care have brought a great deal of attention to patient safety issues. In 1936, four patients died because they received lethal injections caused by a mix up. These adverse events at the Maria Hospital in Stockholm were reported to the police and resulted in a regulation in 1936, Lex Maria (Ödegård 2013). This regulation is still in use today, requiring health care staff to report adverse events in health care. 
In 1983, an incident occurred at the dialysis department at the hospital in Linköping, resulting in the death of three patients. The case received a great deal of media attention, with a focus on the nurse who was involved in the event. She was charged on suspicion of involuntary manslaughter. A similar scenario occurred at a Kalmar hospital in 2002. A nurse was convicted of involuntary manslaughter after giving a fatal infusion to a 3month-old baby. A human technology and organization analysis (HTO analysis) showed that the incident in Kalmar was caused by several faults in the barriers of the system (Ödegård 2013).

Figure 3 provides a rough timeline of patient safety efforts in Sweden, highlighting the three accidents that occurred before the efforts were undertaken in the 2000s. The first patient safety conference in Sweden was organized in 2003 by SALAR, National Board of Health and Welfare and County Councils Mutual Insurance Company (LÖF) in collaboration with all health professional regulatory bodies in Sweden. This conference has been held every 2 years since then and remains an important forum for patient safety researchers and practitioners in Sweden (SOU 2008).

In 2005, a handbook for Risk Analysis and Root Cause Analysis was produced. The County Council of Östergötland provided comprehensive training to any health care staff in Sweden who wanted to make use of the methodology. That same year, a Swedish regulation (SOSFS 2005:12), Quality and patient safety in health care, was issued together with a handbook Good Care, which described the regulation. In 2007, a unit for jurisdictional issues and patient safety was set up at the National Board of Health and Welfare. This department conducts audits to investigate adherence to regulations and how different risks are managed to provide suggestions for improvement in Swedish health care (SOU 2008).

The first comprehensive study in Sweden of adverse events was undertaken by Soop et al. (2009), following an initiative from the National Board of Health and Welfare. The study showed that the magnitude of the problem in Sweden was not smaller than in other countries, underscoring the utmost importance of continued efforts for improved patient safety. In 2008, eight guidelines regarding various patient safety issues (postoperative care, safe care, falls, pressure ulcers, hospital-acquired urinary tract infections, malnutrition, medication errors in health care transitions, infections of central venous catheter, medication-related errors), were distributed by SALAR for implementation and use in the county councils. 
Efforts for improved patient safety in Sweden intensified in 2011. A Patient Safety Law (2010:659) was introduced, providing recommendations and regulations for health care providers to facilitate improvement in patient safety. Also in 2011, a financial incentive plan was launched following an agreement between the Swedish government and SALAR (Appendix A). This incentive allocated over two billion SEK to county councils that performed certain patient safety-enhancing tasks and achieved specific results regarding some patient safety outcomes over the time period 2011-2014 (Ministry of Health and Social Affairs and SALAR 2011). Financial incentives are known to have various effects on clinical decision making (Chaix-Couturier et al. 2000). Financial interests may trump other responsibilities or conflict with evidence. The consequences are sometimes limited continuity of care and underuse or delayed provision of certain services. 
Figure 3. Important events and activities concerning patient safety in Sweden.

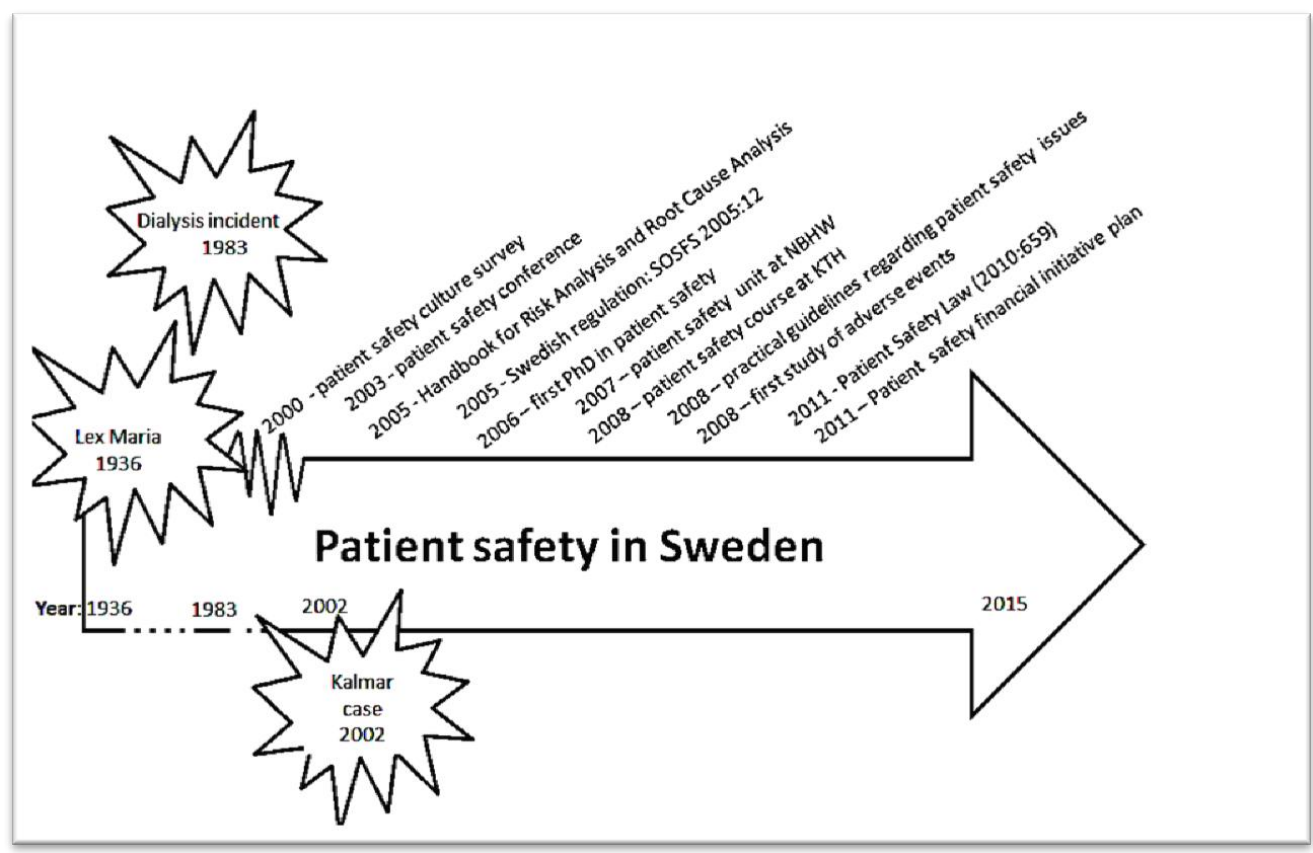

Several actors, i.e. authorities and other organizations, in Sweden have tasks involving patient safety issues. Some of these key actors are briefly described below.

The Swedish Association of Local Authorities and Regions (SALAR) is a members' organization for all the county councils. SALAR represents the county councils and municipalities in dialogue with the Swedish government. They have several different national networks for specific patient safety measures (e.g. HAIs and pressure ulcers) and for patient safety on a broader national scale.

The National Board of Health and Welfare, a government agency under the Ministry of Health and Social Affairs, produces and provides recommendations and regulations for health and social care personnel and managers and monitors the quality of care delivered in Sweden.

The Medical Responsibility Board (Swedish abbreviation, HSAN) is a quasi-judicial authority handling jurisdictional issues relating to the prac- 
tice of health personnel. Issues that the Medical Responsibility Board examines include the probation period; withdrawal of professional licensure or other authorization; practice of a profession in health care while under suspension or limitation on the right to prescribe; new licensure or other authorization. These issues are handled by the board after notification from the Inspectorate for Health Care, or by application from the professional concerned. Even the Parliamentary Ombudsmen, the Ombudsman and the Chancellor of Justice are entitled to report issues to the board. HSAN's decisions can be appealed to the Administrative Court in Stockholm.

The Health and Social Care Inspectorate (Swedish abbreviation, IVO) has the responsibility for supervision of health and medical care. Incidents that have led or could have led to serious health damage must be reported to the Health and Social Care Inspectorate according to the law Lex Maria.

Patients' Advisory committees exist in all county councils. This is an independent and impartial political committee which is assigned to give support and guidance to patients, relatives and staff regarding issues on publicly financed health care (including dental care). Patients can report complaints to the committee, which are then investigated, but the committee does not judge whether health care caused the reported injury or handled the patient in an erroneous way.

County Councils' Mutual Insurance Company (Swedish abbreviation, LÖF) provides tax-financed insurance to all patients in all county councils. Patients may be entitled to compensation if they suffer an avoidable injury caused by health care. 


\section{THEORETICAL FRAMEWORK}

This chapter presents theories and models of relevance for the studies in this thesis. It begins with an explanation of how theory was used in the thesis, with definitions of the concepts, theory and model, and the differences between the two concepts. The remainder of the chapter is devoted to two key theories and models applied in the thesis: Donabedian's triad and learning theory. Important concepts such as context, patient safety culture and patient safety climate are also briefly explained.

\section{Use of theory in the thesis}

Theories concerning how individuals and organizations learn and a model by Donabedian (1966) that deals with health care quality were used in the studies in this thesis. A theory is usually defined as a set of analytical principles or statements designed to structure our observation, understanding and explanation of the world (Polit and Beck 2012). A theory provides an explanation of how and why specific relationships lead to specific events (Polit and Beck 2012). A model typically involves a deliberate simplification of a phenomenon and does not explain the relationship between the concepts of a phenomenon. Models and theories are closely related and the difference is not always clear (models are sometimes called mini-theories). Models can be described as theories with a more narrowly defined scope; a model is descriptive, whereas a theory is explanatory as well as descriptive (Polit and Beck 2012). As used in this thesis, learning theories and the Donabedian model may be considered tools for improved understanding and explanation of patient safety issues.

Learning theories are an integral component of several of the studies in the thesis. While there is no generally accepted definition of learning, there is considerable consensus among learning theorists that learning implies some sort of lasting change (in knowledge, attitudes, self-efficacy, motivation, behaviour, etc.) and that the individual in some way is different from before the learning took place (Kim 1993). Learning is imperative for improving patient safety and is the basis for changes at all levels in health care, from changes in individuals' safety-related knowledge, atti- 
tudes and awareness (conceptual change) to actual behavioural changes (instrumental changes) (Garside 1999; Foy et al.2011; Grol et al. 2005, 2007).

Donabedian's model was used in all five studies in the thesis. The model specifies three aspects of health care (structure, process and outcomes), which is why it is often referred to as Donabedian's triad. The model was complemented in the thesis by a fourth element, context, since the same structure and process elements might lead to very different results depending on contextual differences.

\section{Donabedian's triad (structure, process and outcomes) and context}

In order to understand a practice one must evaluate it, according to Donabedian (1966). His so-called triad is a widely used model to evaluate quality in health care. It consists of three elements: structure, process and outcomes. The basic underlying assumption is that the structure provides conditions for the process, which in turn affects the outcomes. Hence, process may be seen as a proximate influence on outcomes, whereas structure is a more distal influence.

Applied to a patient safety context, the structure can be seen as the conditions for undertaking work and activities aimed at achieving increased patient safety. The structure has to do with how the patient safety work is organized (e.g. in a specific unit or integrated into regular departments, resources and staffing) and the use of various types of support systems and infrastructures for patient safety work. Different forms of rules and regulations may also be viewed as structural aspects because they provide conditions for the patient safety work. Information for evaluating an organization's structure is, according to Donabedian (1966), fairly concrete and accessible.

Process refers to how patient safety work is carried out, e.g. by means of various activities and measures undertaken to improve patient safety. The process element also encompasses various measurements, e.g. of pressure ulcers, HAIs and other problems that need to be controlled or prevented to achieve safer care. According to Donabedian (1966) information for evaluating an organization's processes is less concrete and stable in com- 
parison with structure elements, and therefore harder to measure. It is also more important that dimensions, values and standards are specified explicitly before evaluating the processes.

Patient safety outcome can refer to both safety measures at the patient level and measures of patient safety-related behaviours of health care professionals. Measures at the patient level include the prevalence of HAIs and the incidence of pressure ulcers. Measures of patient safety-related behaviours may include adherence to basic hygiene and dress codes and the number of reported adverse events. It is important to measure outcomes, but outcome measures must be used with discrimination (Donabedian 1966). Identifying and reliably measuring relevant patient safety outcomes represent a tremendous challenge, which is addressed in the Discussion chapter.

The Donabedian model does not explicitly account for the context of the structure, process and outcomes. However, the context is widely recognized as a critically important concept for understanding and explaining patient safety and change in health care (Övretveit et al. 2011; Taylor et al. 2011; Grol et al. 2005). Context lacks an agreed definition in patient safety (and related fields such as quality improvement, implementation science or organizational behaviour). However, context is generally understood as the conditions or surroundings in which something exists or occurs, typically referring to an analytical unit that is higher than the phenomena directly under investigation (Nilsen 2015).

Context in patient safety research is often understood in terms of the patient safety culture or patient safety climate in an organization, department, team or profession. While there is some debate concerning the precise definition of patient safety culture, there is agreement that this culture emerges from the shared assumptions (unspoken beliefs and expectations), values (important and lasting ideals and beliefs) and norms (beliefs about how members of a group should behave in a given context) among members of a group concerning practices that influence patient safety (Guldenmund 2000; Reason, 2000; Patankar et al. 2012). A patient safety culture is usually seen as a subset of a safety culture or an organizational culture, including those parts that specifically relate to patient safety (Guldenmund 2000). Patient safety culture tends to be confused with patient safety climate. However, the culture is understood as deeper assumptions, values and norms, whereas the climate is the surface perceptions and attitudes concerning the observable aspects of culture at a particular point in time (Weaver et al. 2013; Patankar et al. 2012). Further- 
more, the patient safety culture concept emphasizes what is shared by group members rather than the diversity of individual perceptions that can make up a climate (Scott et al. 2003).

\section{Learning}

\section{From data to organizational learning}

Learning is often understood in terms of generating knowledge. The concept of knowledge can be related to data and information. There are different levels of processing needed to progress from unprocessed data to organizational learning. Data are the raw material, which have not been processed yet, e.g. the number of patients with a pressure ulcer. Data have no significance beyond their existence. Thus data must be processed to be meaningful, perhaps presented in a report or memorandum, when it becomes information (Ackoff 1989, referenced in Rowley 2007). Hence, information is data that have been given meaning by way of relational connection, purpose and aim of collection (Ackoff 1989). For this information to be transformed into knowledge requires human interaction with an intelligent and creative mind, and needs to be put into a context, for example, the number of patients with pressure ulcers on a specific ward (which has specific conditions, e.g. patients' diagnoses, patient-staff-ratio, technical aspects and a prevailing safety culture or climate). Knowledge is considered the appropriate collection of information based on how important or relevant it is perceived to be in its problem area (Ackoff 1989). This knowledge may affect our attitudes, subjective norms, outcome expectancies, self-efficacy, motivation and behaviours, thus yielding individual learning, which may be transformed into organizational learning if there are conducive conditions, e.g. opportunities for discussion and reflection with others.

\section{Individual learning}

There are many perspectives on how individuals learn. Behaviourism views learning in terms of behaviour change; unless the behaviour has changed, no learning has taken place. Learning is the result of the individual's response to a stimulus (e.g. provision of information). Reinforcement is an important behaviouristic principle, which posits that in- 
dividuals learn (i.e. behave) to achieve positive (and avoid negative) consequences. Cognitive theories consider behaviour as the result of our perceptions, beliefs, motivation, memory and understanding. Social cognitivism also accounts for learning that accrues from the observation of others. Constructivism assumes that learning occurs when knowledge is constructed by the learner and learning emerges in the interactions between people (Phillips and Soltis 2004).

Experience-based learning originated in the field of cognitive learning and in Piaget's (1896-1980) learning theories. He viewed learning as an adaptation process in which the individual finds equilibrium between his/her existing knowledge and new, sometimes contradictory, knowledge. This enables the transition from one stage to another through assimilation and accommodation. Assimilation denotes the integration of new knowledge, and accommodation is when the existing knowledge is changed to fit the new knowledge. This learning can be seen as an additive learning as it is based on the individuals' former knowledge and experiences. Then new knowledge is added onto the existing frame of mind (Granberg and Olsson 2009).

There are several models of experience-based learning (Kim 1993). One of the most well known is the so-called PDSA cycle (Plan - Do - Study Act). The model is also known as PDSL, with the $\mathrm{L}$ representing Learning. The PDSA cycle was developed by Deming in 1986 and is widely used in Swedish health care improvement work (Thor 2007). The first step in the PDSA cycle is planning for the change, e.g. making statements of aims and identifying outcome measures that will be used to evaluate whether an improvement has been achieved. The proposed change is implemented in step two and the results of the change are studied in step three. In the last step, actions are taken based on the evaluation conducted in step three. The action may be a decision to start a new PDSA cycle with a revised plan and/or revised solution or to standardize the change if it came out well (Deming 1986).

\section{Organizational learning}

Most learning theories deal with individual learning. Organizations are often assumed to learn analogously to individuals, based on the assumption that concepts used in various individual learning theories also apply to the organizational level (Kim 1993). Hence, definitions of organizational learning typically emphasize that this learning implies some type of 
change, which is usually understood in terms of changes in routines, rules or standards that may affect the behaviours of the members of the organization (Kim 1993; Ellström 2010). The concept of organizational learning was first defined by Cyert and March in 1963 (Granberg and Olsson 2009).

Individual learning is considered a necessary, but not sufficient, condition for organizational learning (Kim 1993; Choi and Ruona 2011). Organizational learning is more complex than merely being the sum of individual learning. An important issue in research on organizational learning is how the links between individual and organizational learning look like and how individual learning can be transformed into organizational learning (Kim 1993). A learning organization is competent in creating, acquiring and transferring knowledge, and modifying its behaviour to reflect new knowledge (Choi and Ruona 2011).

The concepts of single- and double-loop learning relate to the depth of individual and organizational learning. The concepts were developed by Argyris and Schön in 1978 (Argyris 2004). Single-loop learning is essentially an error and correction process that permits an organization (or department, team, individuals, etc.) to carry on as previously. Hence, singleloop learning takes the goals and strategies for granted. This learning is the most common. In contrast, double-loop learning involves questioning and modification of the values, norms and assumptions that underlie the goals and strategies. This learning is far more difficult to achieve than single-loop learning (Argyris 2004). 


\section{RATIONALE}

Patient safety is currently high on the agenda of researchers, health care professionals, organizational developers and policymakers in Sweden. Patient safety problems feature regularly in the media. The county councils implement many interventions and quality improvement initiatives, yet there is insufficient evidence or knowledge concerning what structures and processes are most likely to yield better patient safety outcomes and how contextual characteristics may influence the results.

Much patient safety work has been initiated and implemented in Swedish county councils based on recommendations by expert groups at the national level. However, representatives of the organizational/management levels within the county council may have different perceptions about what works and what might be less effective (Damschroeder et al. 2009). Therefore, some of the studies in this thesis investigate perceptions of patient safety officers at the county council level (studies I and V), as well as nurses at a clinical level (study II) on what factors are most important to influence patient safety. Nurses have a special importance with regard to patient safety, as they are the largest professional group in health care and knowledge about their perceptions of the factors that influence patient safety could facilitate the development and implementation of better and more effective solutions.

Measuring HAIs with point prevalence surveys is undertaken in all county councils in an effort to improve patient safety. Several studies have emphasized the importance of HAI surveys for increased awareness of the problem and to generate information to develop appropriate preventive efforts (Emmerson et al. 1996; Eriksen et al. 2005; Humphreys et al. 2008; Lizioli et al. 2003; Lyytikäinen et al. 2008; Van der Kooi et al. 2010). However, we have not found any studies that have actually investigated how or the extent to which surveillance data have been translated into actions to design, implement and assess efforts for reducing HAIs.

Another intervention with the aim of achieving safer care in Sweden is patient safety reports, which are produced annually. The new patient safety law obliges all county councils to compile a report each year on the patient safety work that has been conducted in primary and hospital care, 
and what results have been achieved in the previous calendar year. The aim is to provide a picture of ongoing patient safety work, allowing for tracking of progress over time and identifying areas for improvement. These reports have been published since 2011 and are unique to Swedish health care. 


\section{AIMS}

The overall aim of this thesis was to generate knowledge for improved understanding and explanation of the influences on patient safety in the county councils in Sweden.

The specific aims of the individual studies were the following:

- To investigate the conditions for the county councils' patient safety work (study I).

- To investigate what factors are believed to have been most important in reaching the current level of patient safety and what factors are believed to be most important for achieving improved patient safety in the future (study I, study V).

- To investigate why some county councils are more successful in their patient safety work than others (study V).

- To explore facilitators and barriers influencing patient safety (study II).

- To identify obstacles concerning the HAI surveillance process (study III).

- To describe the patient safety work carried out and reported in the county councils patient safety reports, and to investigate the usefulness of the reports to achieve improved patient safety (study IV). 



\section{METHODS}

This chapter provides details of the methods used in the five studies of this thesis. Table 2 provides an overview of the methodological approaches of each study. The following sections address issues concerning the study setting, study populations, data collection, data analysis and ethical considerations.

Table 2: Methodological approaches of the five studies comprising the thesis

\begin{tabular}{|c|c|c|c|c|}
\hline Study & $\begin{array}{l}\text { Type of } \\
\text { study }\end{array}$ & $\begin{array}{c}\text { Study population } \\
\text { (source of data) }\end{array}$ & Data collection & Data analysis \\
\hline I & Survey & $\begin{array}{l}216 \text { health care pro- } \\
\text { fessionals who held } \\
\text { key positions in their } \\
\text { county council's } \\
\text { patient safety work, } \\
\text { i.e. patient safety } \\
\text { officers }\end{array}$ & $\begin{array}{l}\text { Questionnaire (clo- } \\
\text { sed-ended questions) }\end{array}$ & $\begin{array}{l}\text { Descriptive } \\
\text { statistics }\end{array}$ \\
\hline II & $\begin{array}{l}\text { Qualitative } \\
\text { interview } \\
\text { study }\end{array}$ & 12 nurses & $\begin{array}{l}\text { Semi-structured in- } \\
\text { terviews }\end{array}$ & $\begin{array}{l}\text { Qualitative content } \\
\text { analysis }\end{array}$ \\
\hline III & $\begin{array}{l}\text { Qualitative } \\
\text { interview } \\
\text { study }\end{array}$ & $\begin{array}{l}18 \text { infection control } \\
\text { practitioners }\end{array}$ & $\begin{array}{l}\text { Semi-structured in- } \\
\text { terviews }\end{array}$ & $\begin{array}{l}\text { Qualitative content } \\
\text { analysis }\end{array}$ \\
\hline IV & $\begin{array}{l}\text { Document } \\
\text { analysis and } \\
\text { survey }\end{array}$ & $\begin{array}{l}20 \text { patient safety } \\
\text { reports; } 222 \text { patient } \\
\text { safety officers }\end{array}$ & $\begin{array}{l}\text { Patient safety reports } \\
\text { and questionnaire } \\
\text { (open-ended quest- } \\
\text { ions) }\end{array}$ & $\begin{array}{l}\text { Quantitative content } \\
\text { analysis and qualita- } \\
\text { tive content analysis }\end{array}$ \\
\hline $\mathbf{V}$ & $\begin{array}{l}\text { Qualitative } \\
\text { and quanti- } \\
\text { tative survey }\end{array}$ & $\begin{array}{l}222 \text { patient safety } \\
\text { officers }\end{array}$ & $\begin{array}{l}\text { Questionnaire (clo- } \\
\text { sed-ended and open- } \\
\text { ended questions) }\end{array}$ & $\begin{array}{l}\text { Descriptive } \\
\text { statistics and quali- } \\
\text { tative content analy- } \\
\text { sis }\end{array}$ \\
\hline
\end{tabular}




\section{Study setting}

All five studies of this thesis were undertaken in Swedish county councils. Health care provided by the county councils has many different organizational levels, including the front line practice, the care units and departments, the hospitals, and the county council. The Swedish health care system is financed primarily by taxes levied by the county councils, complemented by government subsidies, and to a small extent, by patient fees. The 21 county councils in Sweden have the decentralized responsibility (from the state) to provide medical care (hospital and primary care) and promote good health for its population (SFS 1982:763). The care of the elderly, support for those after medical treatment and discharge from hospital, visiting nurses and nursing home care, housing and support for those with mental disabilities, are the responsibility of Sweden's 290 municipalities (SFS 1982:763). Municipal care is not studied in this thesis.

Studies I, III, IV and V studied patient safety work at the county council level of Swedish health care. Study II investigated patient safety work at the front line level of care, where health care practitioners are in contact with patients.

\section{Study populations}

In order to reach key informants, i.e. people with first-hand knowledge about patient safety work in Swedish county councils (Marshall 1996), we used both purposive sampling and snowball sampling methods (Polit and Beck 2012). Those two sampling methods can be used together and are suitable when searching for the most information-rich participants who would be of greatest benefit to the different studies (Polit and Beck 2012). There are several different purposive sampling criteria (Polit and Beck 2012).

Study participants in studies I, IV and V were recruited in collaboration with designated members in a SALAR patient safety network, representing all 21 county councils. These representatives were asked to identify respondents whom they considered had "good knowledge and overview of the county council's patient safety work and the ability to influence decisions concerning these efforts", i.e. key informants. The number of patient safety officers from each county council ranged from 3 to 15 , and was fair- 
ly proportional to the population size and health care budget of each county council.

Study II relied on snowball sampling from the above-mentioned study population. We asked for nurses in their respective county councils, who have direct patient contact in their daily work, who might be willing to discuss their patient safety work. Snowball sampling is an approach used when searching for information-rich key informants (Patton 2002; Polit and Beck 2012). After we received the names of potential interviewees, they were contacted consecutively via email with the aim of obtaining heterogeneity with regard to gender and workplace setting, i.e. rural or urban hospital. The nurses all worked in medical hospitals from six different county councils.

Key informants in study III were recruited through an HAI surveillance network at SALAR; coordinators in that network suggested one or two infection control practitioners in their respective county councils who were then invited to participate in the study. Infection control practitioners are assigned to work with HAI surveillance in their respective county councils. Each suggested infection control practitioner was contacted and invited to participate in the study via email. The email contained information regarding the purpose of study, the intended interview questions as well as information regarding voluntary and confidential participation. All infection control practitioners who were contacted agreed to participate.

Study IV was based on examination of the county councils' patient safety reports assembled in 2014. These reports have been compiled yearly by the county councils since 2011, when a new patient safety law came into force in Sweden. These reports describe the patient safety work that has been carried out and what results have been achieved in the previous calendar year. The aim of these reports is to provide a comprehensive picture of the patient safety work, allowing progress to be tracked over time and identifying areas for improvement. The reports document the patient safety work in terms of its structure, processes and results in accordance with the Donabedian model (1966).

\section{Data collection}


All studies used questionnaires and/or interview guides. These can be found in appendices B, C, D and E.

\section{Questionnaire (studies I, IV and V)}

Studies I, IV and V used the same basic questionnaire at two different time points; study I was conducted in 2011 and study IV and V in 2014. The questionnaire was divided into eight sections preceded by a brief introduction explaining why the survey was being undertaken: (1) profession/occupation; (2) number of years involved in a designated task on patient safety issues; (3) knowledge/overview of the county council's patient safety work (Likert-style scale, from poor to excellent knowledge/overview); (4) ability to influence this work (Likert-style scale, from poor to excellent ability); (5) conditions for the county council's patient safety work (18 response items scored on a Likert-style scale, from do not agree to agree completely); (6) importance of various factors in attaining the current level of patient safety in the county council (36 response items scored on a Likert-style scale, from not at all important to very important); and (7) importance of factors to achieve improved patient safety in the future (22 response items, scored on a Likert-style scale, from not at all important to very important, with an additional option of "cannot be improved further"). The eighth section in the questionnaire in study I included space for comments and additional items suggested by the respondents. In the 2014 questionnaire, the eighth section encompassed open-ended questions (studies IV and V) instead.

The 2014 questionnaire added six open-ended questions regarding the patient safety reports (four questions) and perceived reasons why some county councils are more successful in their patient safety work than others (two questions). A background question was also added (concerning whether or not the respondent had participated in the writing of his or her county council's patient safety report). In addition, some of the response items were altered somewhat (e.g. a few items were merged to become one item).

The questionnaire was developed in collaboration with researchers from the Royal Institute of Technology and policymakers from SALAR and the National Board of Health and Welfare, all working with patient safety issues in their organizations. The selection of questions and response items was based on previous studies on the subject (Pukk-Härenstam et al. 2009; Gaal et al. 2011); models of evaluation (Donabedian 1966) and con- 
text and learning from the patient safety work; and discussions among the questionnaire developers. Some of the response items on factors associated with patient safety were obtained from two previous studies (PukkHärenstam et al. 2009; Blendon et al. 2002).

To ascertain that the questionnaire was understood in the way we anticipated, it was reviewed by an expert in respondent psychology and survey methodology. A cognitive interview (Beatty 2004) was conducted with a person who was familiar with the subject of patient safety from a county council perspective.

\section{Interview guide (studies II and III)}

Studies II and III are qualitative studies based on interviews. In study II, semi-structured individual interviews with nurses took place. The first three interviews were conducted face to face in an office of the respondent's choice; the other interviews were conducted by telephone. A semistructured interview guide with open-ended questions was developed by the authors. The interview guide contained questions and probes in four areas: background data; factors for today's level of patient safety; factors for future patient safety; and learning from patient safety work.

For study III, semi-structured telephone interviews with infection control practitioners were conducted. The interview questions used in this study were sent to the respondents along with the invitation email, as we believed the responses would be more comprehensive if they had had a chance to read the questions beforehand. The questions focused on the obstacles perceived in relation to the four stages of the HAI surveillance process, as shown in Figure 4. Obstacles could also be general and therefore not belong to a specific stage.

The stages in the infection surveillance process are consistent with the steps for data to organizational learning. The stages were described both in writing and read to the interviewees during the interviews. The analysis phase starts when the data from a point prevalence measurement of HAIs are collected:

- Collection, compilation and analysis. Data are available in a database and need to be processed, analysed, interpreted, etc. to allow for usage and interpretation. Data and results 
are compiled in different ways, as text, figures, tables, etc., which are reported in memos, reports, etc.

- Dissemination and local interpretation. The data/results from HAI surveillance have been put on paper so that they can be disseminated/communicated to others (except described verbally).

- Implementation. Results are used in different ways, e.g. to plan, decide and implement measures to reduce HAIs.

- Evaluation. This stage involves evaluations of actions and measures taken to lower the rates of HAIs.

Figure 4. Illustration of the HAI surveillance stages as a learning cycle, included in the interview guide.

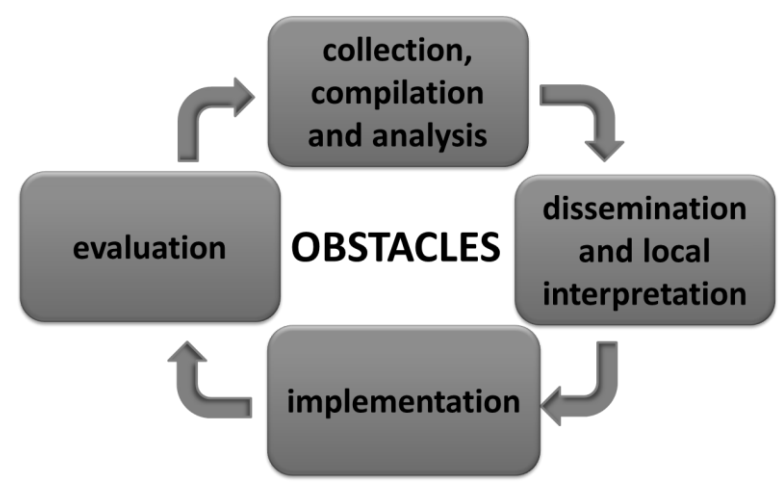

\section{Patient safety reports (study IV)}

The reports analysed in study IV were collected from the county councils' websites in March 2014 (16 reports). The five county councils that did not have a report available on their website were contacted and asked to provide their report directly to the researchers. Four of these county councils provided their report via email. The fifth county council replied that they were currently compiling their report, but they would not be able to complete it in time for the study. 


\section{Data analysis}

\section{Statistical analysis}

Descriptive statistics were used to analyse the responses to the questions in the survey questionnaires used in studies I and V. Descriptive statistics are used to answer "what" is going on, and repeated descriptive surveys can describe changes in this "what" over time (Greenfield 2002).

Data from the questionnaires were entered and coded independently into a Microsoft Office Access database. The database was examined by a statistician (who participated in the study), who made the initial coding scheme to validate all the data entries. First in the analysis, the frequencies for each question were calculated. To make comparison between the different questions and items easier, we presented the responses in percentages. The Likert-style items were arranged in order of highest percentage "very important" or "agree completely" responses. The descriptive statistics were calculated using SPSS.

After analysis of the data, it became evident that the response items concerning the use of SALAR's action plans ( 8 items) and guidelines ( 3 items) could be merged to only two items. In study V we named these two items as: "Use of one or more of SALAR's action plans (e.g. falls, malnutrition, etc.)", "Use of one or more of SALAR's guidelines (regarding patient safety issues)".

\section{Content analysis}

Qualitative content analysis was used in all studies except study I. Content analysis is a straightforward method when analysing texts containing empirical data with an explorative and descriptive character. The method involves a structured analysis process to code and categorize the data (Hsieh and Shannon, 2005). There are several types of content analysis in the literature, and the analysis can be either qualitative or quantitative. The difference between these two approaches is that quantitative content analysis is driven by a deductive approach with a search for the frequency of words previously determined, and qualitative content analyses have a more inductive and interpretative approach (Schreier 2012). Although the qualitative approach can use a deductive approach, the frequency of 
words is never counted (Schreier 2012). According to Schreier (2012), the framework for coding data is at the heart of qualitative content analysis, hence the coding framework determines what to look for in the data. The framework is the focus that helps the researcher to narrow down data in the material, in accordance with the research questions and the aim of the study (Schreier 2012).

The content analysis researcher can always expand the chosen framework (see below in the description of the analysis in study II) during the research process. That is, if something new emerges from the data, the framework can be changed, or a new one can be added. The framework does not impose deductive emergence of categories in the analysis process, and should be viewed more as a concept rather than a static coding frame.

The following steps (although not always in this sequence) were taken during the content analysis in studies II, III, IV and V:

- Read the collected material (transcribed interviews, open answers and patient safety reports)

- Start coding, first by highlighting "meaning units" in the text and then label (code) them; a meaning unit is a coherent and distinct section of the written text

- Categorize codes into the framework

- Scrutinize and iterate coding and/or categorization

- Apply triangulation analysis/consistence analysis (compare and discuss coding with other person(s) who also coded data)

- Interpret and present the findings

The analytical process was the same for studies II, III and IV, but the frameworks for coding differed as described below.

In study II, the analysis started with an inductive approach but later in the analysis, a framework for analysing risk and safety developed by Vincent et al. (1998) was used. However, this framework was applied late in the analysis process. The analysis was broad at the start in order not to influence or steer the interviewees too much, but after the analysis began, it was evident that the facilitators and barriers found in our data could be classified according to the Vincent framework of contributory and influencing factors on safety (Vincent et al. 1998). QSR NVivo 9 was used for data management. 
Study III used the same framework as that developed for the interview guide to analyse what obstacles occurred during the four stages of the HAI surveillance (Figure 4). Coding consisted of marked meaning units in the transcribed interviews, which were then sorted into categories, i.e. various types of obstacles. These categories were derived inductively from the data. Obstacles could also be general and therefore not belong to a particular stage in the surveillance process.

For studies IV and V, open-ended questions in the questionnaire were analysed with qualitative content analysis to answer the research questions and to derive categories inductively from the data.

In study IV the patient safety reports were analysed with quantitative content analysis. The coding framework for the reports was developed and has been used since the reports were first published in 2011. This coding scheme consisted of the three categories of the Donabedian triad: structure, process and outcomes, containing subcategories i.e. elements within each category. The elements were revised during the analytical process. The analysis followed the above-mentioned steps for the content analysis.

As the coding and categorization progressed, the process and structure elements were assigned one of four labels: implemented; partly implemented (i.e. all health care facilities in a county council had partially implemented a structure or process element or the structure/process element had been fully implemented in some facilities but not in all); unclear reporting (i.e. mentioned, but impossible to judge if implemented or not); or not reported. The presence of outcome elements was coded as either "yes" or "no". Data were entered into Microsoft Excel 2010 for data management.

\section{Ethical considerations}

Ethical approval was obtained for study II from the Regional Ethical Review Board in Linköping (reference number, 2012/249-31). The remaining studies did not require ethical approval because they did not involve sensitive personal information, as specified in Swedish law regulating ethical approval for research concerning humans (SFS (2003:460) Lag om etikprövning av forskning som avser människor). Unless approval has 
been obtained from an authorized ethics committee, it is forbidden to collect and process personal data revealing: racial or ethnic origin; political opinions; religious or philosophical beliefs; union membership; data concerning health; or sex life. However, this did not apply to any of the studies.

Numerous steps were taken during the research project to minimize any threats to personal integrity. Questionnaire respondents in studies I, IV and $\mathrm{V}$ were informed that participation was voluntary and that personal information was handled confidentially. Information on the respondents was only traceable to individuals through a coding key kept safe by the primary researcher.

At the time of the interviews in studies II and III, background data were gathered that could not be traced to the individual level. Informed and voluntary consent was given both in writing (via email contact) and orally (at the interview). Participants were informed that they could withdraw at any time during the interview and that the data would be handled with confidentiality. Transcribed material was de-identified and coded with a number. 


\section{RESULTS}

This chapter presents the results from the five studies in abbreviated form. The full results can be found in the appended papers.

\section{Study 1}

Study I investigated the conditions for the county councils' patient safety work, what factors are believed to have been most important in reaching the current level of patient safety and what factors are believed to be most important for achieving improved patient safety in the future, using a survey questionnaire to patient safety officers. Patient safety officers were defined as people within the county councils who had a designated task involving patient safety issues, had knowledge/overview of the county council's patient safety work, and had the ability to influence this work.

The questionnaire was sent to 218 patient safety officers. Two officers had resigned from their respective county councils and thus did not receive the questionnaire, resulting in a study population of 216 . Of these, 171 people answered the questionnaire, yielding a response rate of $79 \%$. Three respondents were excluded from the analysis due to incomplete answers. Two-thirds of the respondents (65\%) had been designated to work with patient safety issues in their county council for 3 years or more. Twothirds (65\%) felt that they had excellent or very good knowledge of the county council's patient safety work, and $42 \%$ believed that they had excellent or very good ability to influence the patient safety work in their county council.

The conditions with the highest number of responses in complete agreement were "patients' involvement is important for patient safety" (43\%) and "patient safety work has good support from the county council's management" (32\%). All other response items had considerably lower rates of "agree completely" replies ranging from $17 \%$ to $1 \%$.

More than half of the respondents considered seven factors as "very important" for the current level of patient safety in the county council. Factors that were rated highest included "conducting root cause and risk 
analyses" (66\%), "incident reporting" (63\%) and "the Swedish Patient Safety Law" (60\%). Approximately one-third of the respondents believed the use of various SALAR guidelines were very important for attaining the current level of patient safety.

Six factors for achieving improved patient safety in the future were considered "very important" by more than $60 \%$ of the respondents. The highest proportions were noted for "improvement of organizational culture that encourages reporting and avoids blame" (83\%), "improved communication between health care practitioners and patients" (80\%), "improved communication among health care practitioners" (78\%) and "Incorporation of patient safety education as a compulsory component of basic education for health care practitioners" (77\%).

\section{Study II}

Study II explored facilitators and barriers to patient safety, as perceived by registered nurses in general hospital care in Sweden. Eleven female nurses and one male nurse, all with direct patient contact, were interviewed. All were registered nurses (referred to simply as nurses in the study). Their average age was 48 years (range, 27-63 years) and they had worked on average 19 years as nurses (range, 4-40 years). The nurses came from eight somatic hospitals in Sweden in six county councils.

The nurses identified 22 factors that influenced patient safety, of which 12 functioned as both facilitators and barriers, six constituted barriers, and four were facilitators (Table 3). The factors belonged to seven different levels, ranging from patient interaction and individual staff to institutional context. There were no specific patterns in which barriers or facilitators were more common at any level. Rather, they were quite evenly distributed at the different levels. 
Table 3. Barriers and facilitators for patient safety as perceived by registered nurses. Some of the identified factors could act either as a barrier or a facilitator.

\begin{tabular}{|c|c|}
\hline Domains & Barriers $(B)$ and facilitators $(F)$ \\
\hline Patient factors & $\begin{array}{l}\text { - Patient interaction }(\mathrm{B}+\mathrm{F}) \\
\text { - }\end{array}$ \\
\hline $\begin{array}{l}\text { Individual staff } \\
\text { factors }\end{array}$ & $\begin{array}{l}\text { - } \text { Interest and knowledge (F) } \\
\text { - } \quad \text { Skills and abilities (B + F) } \\
\text { - } \quad \text { Feelings (B) } \\
\text { Fallibility (B) }\end{array}$ \\
\hline Team factors & $\begin{array}{l}\text { - Collaboration in multi-professional teams }(\mathrm{B}+\mathrm{F}) \\
\text { - Communication with colleagues }(\mathrm{B}+\mathrm{F})\end{array}$ \\
\hline $\begin{array}{l}\text { Task and techno- } \\
\text { logy factors }\end{array}$ & $\begin{array}{l}\text { - Collecting, storing and sharing patient safety-related data and information (B + F) } \\
\text { - Medical records (B + F) } \\
\text { - Incident reporting (B + F) } \\
\text { - } \text { Computerized technology (B + F) } \\
\text { - Written protocols (F) }\end{array}$ \\
\hline $\begin{array}{l}\text { Work environmen- } \\
\text { tal factors }\end{array}$ & $\begin{array}{l}\text { - } \text { Structures and forums for learning from errors }(\mathrm{B}+\mathrm{F}) \\
\text { - } \\
\text { - }\end{array}$ \\
\hline $\begin{array}{l}\text { Organizational and } \\
\text { management } \\
\text { factors }\end{array}$ & $\begin{array}{ll}\text { - } & \text { Leadership }(\mathrm{B}+\mathrm{F}) \\
\text { - } & \text { Financial resources }(\mathrm{B})\end{array}$ \\
\hline $\begin{array}{l}\text { Institutional context } \\
\text { factors }\end{array}$ & $\begin{array}{l}\text { - Use of knowledge from external sources }(\mathrm{B}+\mathrm{F}) \\
\text { - Communication with people external to the workplace (B) } \\
\text { - Societal interest in patient safety (F) }\end{array}$ \\
\hline
\end{tabular}

\section{Study III}

The aim of study III was to identify key obstacles concerning the different stages of the county councils' HAI surveillance process: (I) data collection, compilation and analysis of results from the point prevalence surveys; (II) dissemination and local interpretation of the point prevalence survey results; (III) use of the point prevalence survey results in efforts to reduce HAIs; and (IV) assessment of the efforts undertaken on the basis of the point prevalence survey results. Obstacles could also be general, i.e. not refer to a specific stage. Obstacles were defined as difficulties, problems and challenges concerning the county councils' use of point prevalence survey results in efforts to reduce HAIs. 
Interviews were conducted with infection control practitioners, who are assigned to work with HAI surveillance in the county councils. Of the infection control practitioners who took part in 18 interviews that were analysed for the study, four had worked with HAI issues for 1-2 years, 12 for 3-5 years and one for more than 5 years (one person did not answer this question). The infection control practitioners ranked their knowledge and overview of their county council's HAI surveillance work as good (five persons), very good (eight persons) or excellent (four persons) (one person declined to answer). Many different professional groups and titles were represented among the infection control practitioners, including chief physicians, physicians, nurse managers, nurses, infectious disease experts, hygiene experts and patient safety coordinators (more than one profession/position could be given). An equal number of men and women were interviewed.

Five types of obstacles emerged from the analysis of the data:

- Technical barriers to working with HAI data and results

- Questionable reliability and applicability of HAI data and results

- Insufficient resources for working with HAI issues

- Lack of interest, competence and understanding regarding HAI issues

- Lack of strategies for working with HAI issues.

Altogether 16 obstacles belonging to these five categories were discussed by the infection control practitioners with respect to the county councils' use of HAI results in preventive efforts. Most obstacles were associated with the first two stages of the HAI surveillance process, which meant that the latter stages of this process, i.e. actually using the results in efforts to reduce HAI, were hindered. Many obstacles that were described by the infection control practitioners restricted the actual use of results in effort to reduce healthcare-associated infections.

\section{Study IV}

Study IV sought to describe the patient safety work carried out in Sweden by analysing the patient safety reports assembled by all county councils. Twenty of the 21 county councils in Sweden provided a complete report for 2014. One county council published a number of individual reports 
pertaining to different health care organizations operating within the county council. These were not included in the analysis. The content of the reports was classified into the structure, process and outcome of the patient safety work, in accordance with the Donabedian model (1966).

The study also investigated the perceived usefulness of the patient safety reports as a tool to achieve improved patient safety in the county councils. To this end, a questionnaire survey was sent to 222 health care practitioners identified as having a strategic position in patient safety work in the county councils, i.e. the same study population as in study V. Two open questions were used to capture the perceived usefulness of the reports (these questions were part of the same questionnaire used in study V).

With regard to the structure of the patient safety work, 14 different elements were identified in the reports. The majority of the county councils, 14 of 20, reported between 6 and 10 structural elements in their reports. The most frequently reported elements were the so-called STRAMA groups commissioned to work with issues of antibiotic utilization (reported by all county councils) and electronic incident reporting systems (reported by 19 county councils). STRAMA is a multi-professional national network with the aim of achieving rational use of antibiotics in Swedish health care at the county council level. Fourteen of the 20 county councils reported partial implementation of a national electronic system to prevent and reduce HAIs and incorrect antibiotic prescriptions (called the Infection Tool).

Thirty-one different process elements could be identified in the reports. Half of the county councils reported between 11 and 15 process elements in their reports. Six county councils reported between 16 and 20 process elements and two reported 21 or more process elements. Eighteen county councils reported measured point prevalence of HAIs; compliance with basic hygiene and dressing rules; and prevalence of pressure ulcers. The presence of action plans based on the results from patient safety culture surveys were also reported by 18 county councils.

The reports included 23 different outcome elements. Thirteen of the 20 county councils reported between 11 and 15 outcome elements and three reported between 16 and 20. Nineteen county councils reported results concerning HAI and compliance with basic hygiene rules and dress codes, and 18 reported results with regard to pressure ulcers, incidents in reporting systems and Lex Maria, which is a law dictating that health care or- 
ganizations in Sweden are obliged to report all severe incidents to the Health and Social Care Inspectorate.

Based on the qualitative analysis of the open-answer questions, three types of perceived usefulness of the patient safety reports emerged:

- The patient safety report provides a structure for patient safety work

- The patient safety report enhances the focus on patient safety

- The patient safety report contributes to learning about patient safety

\section{Study V}

Study V sought to investigate what factors are believed to have been most important in reaching the current level of patient safety and what factors are believed to be most important for achieving improved patient safety in the future, as well as to investigate why some county councils are more successful in their patient safety work than others, as perceived by patient safety officers. Essentially the same survey questionnaire and participants were selected from the same population as in study I, i.e. patient safety officers, health care professionals with strategic positions in patient safety work in the 21 county councils in Sweden.

Of the 222 patient safety practitioners who were sent the questionnaire, 156 responded, yielding a response rate of $70 \%$. Fifty-five of the respondents provided responses to the open question to identify "success factors". Three-quarters of the respondents (75\%) had been designated to work with patient safety issues in their county council for 3 years or more. Approximately two-thirds (68\%) believed that they had excellent or very good knowledge of the county council's patient safety work, and one-third (33\%) believed that they had excellent or very good ability to influence the patient safety work in their county council.

More than half of the respondents considered five factors as very important for having attained the current level of patient safety in the county council. Factors that were rated highest included efforts to reduce the use of antibiotics (62\% stated this was very important), Swedish patient safety law (62\%) and internal discussions with the county council management, heads of health care units, health care providers, etc. (58\%). Other noteworthy results were that relatively few of the respondents perceived pa- 
tient safety culture surveys (26\%), research and scientific articles about patient safety (23\%) and information from various quality registers (18\%) to be very important factors.

Six factors for achieving improved patient safety in the future were considered very important by more than $60 \%$ of the respondents. The highest proportions were noted for improved communication between health care practitioners and patients (85\%), improved organizational culture that encourages reporting and avoids blame (79\%), improved communication among health care practitioners $(78 \%)$ and incorporation of patient safety knowledge as a compulsory component of basic education for health care practitioners (73\%). An increase in the number of nurses was considered to be very important by $29 \%$ of the respondents, whereas $19 \%$ considered increased numbers of physicians to be very important.

Four key factors emerged from the analysis of factors that the respondents believed characterized the most successful county councils:

- Leadership support for patient safety

- Well-organized patient safety work

- Long-term commitment to patient safety

- Organizational culture that is conducive to patient safety

Each of these four factors was expressed by five or more respondents. 
Towards safer care in Sweden? 


\section{DISCUSSION}

This thesis aimed to generate knowledge for improved understanding and explanation of influences on patient safety in the county councils in Sweden. The results from the individual studies are discussed in the papers appended to this thesis. This discussion focuses on the findings in relation to Donabedian's triad and learning theory presented in Chapter 3. The chapter also addresses methodological issues of the studies and presents implications, thoughts on future research and conclusions.

\section{A framework for understanding and explaining in- fluences on patient safety in the county councils}

I use a theoretical framework to structure the findings of the studies, which combines Donabedian's triad (plus the context) and the concepts of single- and double-loop learning (Figure 5). The framework conveys that single-loop learning ("doing things right") occurs when the process is changed without challenging existing patient safety-related goals or strategies. However, to achieve more profound and sustainable changes, double-loop learning is required, which depends on changes in the patient safety structures and context so that the values, norms and assumptions that underlie present goals and strategies can be questioned and modified. This framework allows for a review and discussion of important results from the five studies. 
Figure 5. The SPOCL framework that combines the Donabedian triad and context with Argyris and Schön's single and double-loop concepts (modified from Nilsen et al. 2012).

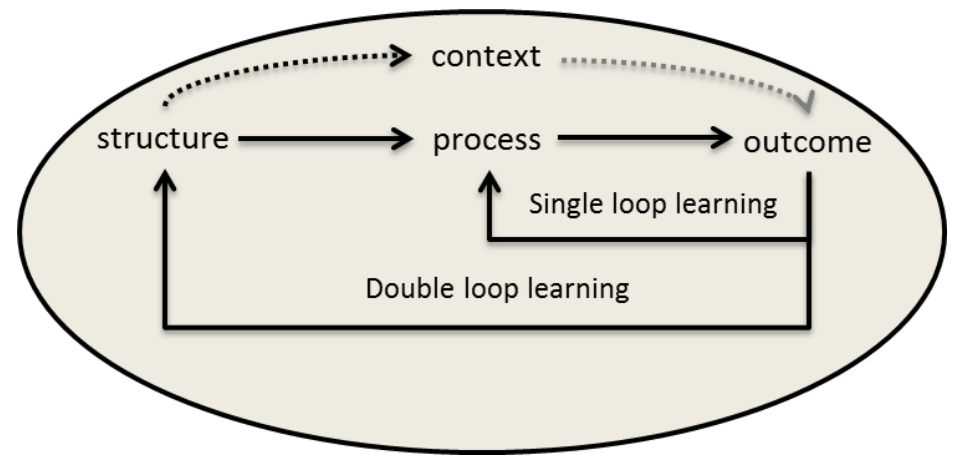

\section{Potentially important areas for safer care in Sweden}

When considering the findings of the five studies in terms of the SPOCL framework, two areas might be seen as particularly salient in the county councils' efforts to achieve improved patient safety: infection control and learning from errors. Other important areas for improving patient safety according to the studies include patient safety culture/climate, education on improved patient safety, patient involvement, patient safety legislation and the work environment. However, although these areas of potential relevance for improving patient safety in the county councils emerged from the studies, it is important to emphasize that the degree to which they actually influence patient safety was not assessed. Instead, the studies are based on perceptions from patient safety officers, nurses and infection control practitioners, as well as on description of the reported patient safety work carried out in the county councils.

\section{Infection control}

Several of the studies (I, III-V) addressed infection control issues in relation to all of the elements in the SPOCL framework (Table 4). 
Table 4. Findings from study I, III, IV and V with regard to the elements of the SPOCL framework.

\begin{tabular}{|c|c|c|}
\hline $\begin{array}{l}\text { SPOCL-framework } \\
\text { elements }\end{array}$ & Important findings concerning infection control & Study \\
\hline \multirow[t]{5}{*}{ Structure } & $\begin{array}{l}\text { Implementation of the national electronic system } \\
\text { to prevent and reduce HAIs and incorrect antibio- } \\
\text { tics prescription: the Infection Tool }\end{array}$ & IV \\
\hline & $\begin{array}{l}\text { Implementation of STRAMA group (a multi- } \\
\text { professional national network with the aim of } \\
\text { achieving rational use of antibiotics in Swedish } \\
\text { health care) }\end{array}$ & IV \\
\hline & $\begin{array}{l}\text { Technical barriers with point prevalence surveys } \\
\text { of HAIs data and results }\end{array}$ & III \\
\hline & $\begin{array}{l}\text { Insufficient resources for point prevalence surveys } \\
\text { of HAIs }\end{array}$ & III \\
\hline & $\begin{array}{l}\text { Lack of strategies for point prevalence surveys of } \\
\text { HAIs }\end{array}$ & III \\
\hline \multirow[t]{4}{*}{ Process } & Improved infection control & I \\
\hline & Efforts to reduce the use of antibiotics & $\mathrm{V}$ \\
\hline & $\begin{array}{l}\text { County councils are performing point prevalence } \\
\text { surveys of HAIs }\end{array}$ & IV and III \\
\hline & $\begin{array}{l}\text { County councils are performing point prevalence } \\
\text { surveys of hygiene and dressing rules }\end{array}$ & IV \\
\hline \multirow[t]{2}{*}{ Outcome } & $\begin{array}{l}\text { County councils are performing point prevalence } \\
\text { surveys of HAIs }\end{array}$ & IV \\
\hline & $\begin{array}{l}\text { County councils are performing point prevalence } \\
\text { surveys of hygiene and dressing rules }\end{array}$ & IV \\
\hline \multirow[t]{2}{*}{ Context } & $\begin{array}{l}\text { Lack of interest, competence and understanding of } \\
\text { point prevalence surveys and/or HAIs }\end{array}$ & III \\
\hline & $\begin{array}{l}\text { Questionable reliability and applicability of HAI } \\
\text { data and results }\end{array}$ & III \\
\hline Learning & $\begin{array}{l}\text { Most obstacles were associated with the first two } \\
\text { stages of the HAIs surveillance process, which } \\
\text { meant that the latter stages of this process, i.e. } \\
\text { actually using the results in efforts to reduce HAIs, } \\
\text { were hindered }\end{array}$ & III \\
\hline
\end{tabular}

Considering the risks associated with the use of antibiotics and antimicrobial resistance (World Health Organization 2014), the emphasis on the importance of these issues in the studies is not surprising (and study III had this particular focus, investigating surveillance of HAIs). The results combined from studies I, III, IV and V suggest that this is an important 
area, which seems to be in transition. In the most recent survey (study V), the items regarding infection control were rated considerably lower than in the first survey (study I), which may indicate that interventions (hand hygiene promotion and surveillance of HAIs, etc.) undertaken in the county councils have not led to the expected improvements over time. However, when an organization looks for new and better efforts and or intervention, and modifies its behaviour according to new knowledge, it behaves like a learning organization (Choi and Ruona 2011).

Two (or more) annual point prevalence surveys of HAIs have been conducted since 2008 in all county councils, and the results have been disseminated nationally to allow for comparisons between county councils. However, study III showed that many infection control practitioners expressed doubts regarding the point prevalence methodology in use, and the study pointed to many obstacles regarding all the steps of the surveillance process. More recently, county councils have started implementing a national electronic system called the Infection Tool, which uses incidence data from the medical records (the tool requires detailed information when antibiotics are prescribed). The tool provides local data on prescriptions and HAI status to enhance learning among practitioners, and it has been partially implemented in secondary care settings (hospital care) in 14 county councils.

Reduction in the use of antibiotics is a major improvement area in many countries (Finch 2012; McNulty et al. 2012; Gray et al. 2012). In Sweden, all county councils have a local STRAMA team working for more restrictive use of antibiotics. In France, similar teams have been successful in gaining institutional control over specific HAIs (Fournier et al. 2012).

\section{Learning from errors}

Learning from errors is another area where the findings from all the studies apply to all the elements of the SPOCL framework. Studies I, II and IV showed that learning from incident reporting systems is considered important for patient safety and nurses in study II mentioned computerized technology and opportunities for learning as essential to learn from each other within the organization (structure elements). In studies I and V, root cause and risk analyses and incident reporting (process elements) were the highest rated factors for attaining the current level of patient safety. Almost all of the patient safety reports in study IV reported the number of incident reports and Lex Maria reports (outcome elements). 
The findings concerning the perceived importance of incident reporting are not surprising because this has long been considered essential for patient safety work in Sweden and elsewhere (Gaal et al. 2011; Vincent 2010). In Sweden, the incident reporting systems are local to each county council and every clinic has access to its own results, which is vital in order to learn from errors (Stavropoulou et al. 2015). Incident reporting systems have the potential to improve patient safety if they enable learning from the reported risks and incidents. However, the focus of research thus far has not been on how or to what extent these systems can yield appropriate learning at individual and organizational levels.

Many county councils report the number of the incident reports although the number is not a reliable patient safety outcome (Benn et al. 2009). Incident reporting systems are credited with improving safety in high-risk industries such as aviation, nuclear power, and petrochemical processing, leading to the assumption that these systems can also offer valuable learning for health care. While the potential relevance of incident reporting systems for health care is widely accepted, reliance on these systems to improve patient safety has also met with some scepticism (Leape 2002; Vincent 2007). Reporting of risks and incidents has been questioned in Sweden, with some researchers calling for a stop to reporting altogether because convincing evidence that this practice has improved patient safety in Sweden is lacking (Gunnarsdotter 2013).

Incident reporting is not the only means of learning from risks and incidents in health care. The nurses in study II emphasized the importance of having meetings at which they can discuss and reflect on adverse events for increased learning. This suggests the need to supplement incident reporting with learning-oriented forums and other types of information from patients and retrospective record reviews (Thomas and Petersen 2003; Olsen et al. 2007; Sari et al. 2007; Vincent 2007; De Feijter et al. 2012; Westbrooks et al. 2015). The reporting and analysis of risks need to be linked to appropriate action and feedback in order to improve patient safety. More attention needs to be given to how systems and instruments can be used for organizational learning (Vincent 2010; Gandhi et al. 2005; Battles and Stevens 2009; Benn et al. 2009; Wallace et al. 2009). In a review of studies on incident reporting systems, Stavropoulou et al. (2015) found evidence of single-loop learning in 33 of the 35 studies, with examples of improvements in procedures and implementation of new guidelines. They found limited evidence that the incident reporting systems fostered double-loop learning; for example, a more open reporting of risks and incidents or a more supportive patient safety culture. 
Somewhat surprisingly, retrospective medical record reviews did not rank highly in either study I or study V. This approach to estimating patient safety outcomes is conducted in $75 \%$ of the county councils (study IV). The disparity between the perceived limited importance of retrospective medical record reviews for improving patient safety (studies I and V) and its widespread implementation (study IV) does not necessarily mean that it is a poor tool for generating learning from errors, but perhaps other patient safety tools are more visible and more widely used. Retrospective record reviews are performed by specially trained health care staff, and the approach is not integrated in the daily health care practice. The method is useful in detecting adverse events including no-harm incidents, and is considered useful by those who perform the analysis (Schildmeijer 2013). However, retrospectively identifying adverse events may contribute to a blame and shame culture where staff might feel scrutinized by experts, which would impede double-loop learning (Stavropoulou et al. 2015). More than likely, the high degree of implementation of the approach can be linked to the financial incentive plan; conducting retrospective record reviews is a mandatory requirement to be eligible for the performance-based additional reimbursement.

\section{Patient safety culture}

All studies in this thesis point to the relevance of patient safety culture for improving patient safety. On the basis of the SPOCL framework, we found that all county councils measure the patient safety culture with patient safety surveys (study IV), and 18 of 20 county councils reported action plans based on the results from these surveys. According to the survey studies (studies I and V), the process of patient safety culture measurement itself was not believed to be particularly important for current or future patient safety levels. This may be due to the fact that measurement of patient culture is a relatively new activity (initiated in 2011) in comparison with, for example, the measurement of HAIs and hand hygiene. The county councils use guidelines concerning work with infections and hygiene, but there is no consensus on what actually improves the patient safety culture (Weaver et al. 2013).

The high level of reporting on the culture surveys may be because these measurements and action plans are mandatory requirements to be eligible for reimbursement from the financial incentive plan. This could mean that the culture as such is considered important for patient safety, but the measurement of this culture seems to have had limited impact on patient 
safety. Other areas relating to the context element of the SPOCL framework have more obvious links with patient safety, such as an organization free from blame and shame (studies I and V), supportive management (studies I, II, III and V), communication between health care practitioners and between practitioners and patients (studies I, II and V) and collaborations in multi-professional teams (study II).

Open communication based on mutual trust is usually considered an integral aspect of a positive patient safety culture (Vincent 2010). Although there is emerging evidence to support the potential effectiveness of interventions aimed at improving safety culture (Weaver et al. 2013), the culture concept is undeniably complex and it is unclear what aspects of the patient safety culture are in most need of improvement and whether these improvements can be achieved (Ginsburg et al. 2009). Research is needed on how culture survey results can be transferred back to the frontline personnel and the managerial level in order to create learning from the measurements.

\section{Patient safety education}

The need for training in patient safety to achieve improved patient safety was a theme in all the studies. The need for patient safety knowledge in basic training for health care practitioners was at the top of the list of factors that the respondents believed were most important to achieve improved patient safety in the future in studies I and V. "Interest and knowledge" and "skills and abilities" were mentioned in study II as facilitators for improving patient safety. In study III, lack of interest, competence and understanding was an obstacle to making use of and learning from the point prevalence surveys of HAI results. Sixteen of 20 county councils reported that they provide some kind of education/training in patient safety to their staff in study IV.

Patient safety is not a compulsory subject in basic education for any health profession in Sweden. The availability of courses in patient safety differs considerably among the Swedish universities (Swedish National Audit Office 2015). The focus in the training provided by the county councils has mostly been on team-based training and simulation training, whereas more general patient safety knowledge has received less attention (Swedish National Audit Office 2015). To increase health care practitioners' understanding and knowledge of patient safety, the Swedish National 
Audit Office (2015) highlights the need for more and structured education for health care professionals in patient safety within basic education.

\section{Patient involvement}

In studies I and II, patient involvement was seen as an important factor for improved patient safety. However, it should be noted that there was limited agreement with the statement "patient complaints and reports are systematically analysed and followed up" in study I. This discrepancy reflects the lack of consensus on how and in what way patients should and can be involved and whether or the extent to which patient engagement contributes to safer care (Ward et al. 2011; Longtin et al. 2010; Byrd and Thompson 2008). There is also a paucity of research on how the patients accept their new role (Longtin et al. 2010; Byrd and Thompson 2008). More research is needed to progress from rhetoric to practice, in order to develop strategies for improving patients' involvement in their own care (Ward et al. 2011; Hall et al. 2010; Davis et al. 2011; Pittet et al. 2011).

\section{Patient safety legislation}

The importance attributed to the Patient Safety Act in studies I and V for attaining patient safety was surprising considering it was a new law introduced in 2011. Hence, it was too new to have been able to affect the county councils' work. The nurses in study II did not mention the law as being a factor that contributed to patient safety. The law may have served as a leverage tool for the patient safety officers at the county council level, supporting their efforts for improved patient safety by raising awareness of the issue on a broader scale. It seems likely that the law has raised the importance of patient safety higher on the agenda in the county councils, alongside production and economic goals and priorities.

\section{Work environment}

There are some contradictory findings from the studies with regard to the importance of the work environment and workforce issues for patient safety. Patient safety officers (studies I and V) did not consider reduced working hours for physicians or increased numbers of nurses as important, but both the nurses in study II and infection control practitioners 
in study III expressed the opinion that staffing levels and the physical environment are of great importance for efforts to achieve improved patient safety. It is noteworthy that issues concerning the workforce or work environment issues are not reported in the patient safety reports (study IV).

The number of nurses in health care was considered more important in the survey in study V than study I, a change that might be due to the influence of a high-profile study (Aiken et al. 2014) on the patient safety officers. This study demonstrated that the higher the ratio of nurses to patients, the safer the care. Several previous studies have proved that fatigue impairs clinical work (Fletcher et al. 2005; Landrigan et al. 2004) and that issues related to workload, the physical environment and nursing shortages are of importance to the patient safety status (Nicklin and McVeety 2002; Blendon et al. 2002). A partial explanation for our findings is that the respondents in studies I and V were not frontline health care practitioners. Studies have shown that the perception of patient safety and how it can be improved differs depending on the person's position in the health care system (van Beuzekom et al. 2013; Richardson and Storr 2010; Amalberti et al. 2005) and on the profession (Listyowardojo et al. 2012; Gallego et al. 2012). Another partial explanation is that an increased number of nurses is not seen as a patient safety intervention but a fundamental necessity in the health care organization that always has to be handled.

\section{Multiple influences on patient safety}

The aim of this thesis was to contribute to an improved understanding and explanation of the influences on patient safety in the county councils. The studies have highlighted certain areas that are considered important for patient safety according to those surveyed or interviewed in these studies. Does that mean we know what the most important influences on patient safety are? No, it does not. The difficulty in conceptualizing and measuring patient safety outcomes and study interventions under controlled research conditions makes it hard to identify specific activities that lead to improved patient safety. Efforts for increased patient safety have a tendency to be complex and multifaceted, directed at many different levels, including individual health care practitioners, teams, professions, departments and county councils, and employ many different strategies (Shekelle et al. 2011). Hence, much patient safety work is essentially experience-based or expert-based rather than relying on solid evidence of effectiveness of numerous interventions (Shekelle et al. 2011; Goeschel et al. 2010). These difficulties notwithstanding, the five studies of this thesis 
have highlighted certain areas with potential to have an important impact on patient safety.

\section{Methodological considerations}

The studies in this thesis have a number of limitations that must be considered when interpreting the findings. The studies do not provide the whole or a definitive picture of the patient safety work currently being carried out in Swedish county councils. Depending on what methodology is used and from what perspective one looks, the picture of the patient safety problem will look different (Shojania 2010). The studies take an organizational perspective to patient safety and highlight various aspects of the county councils' patient safety work.

\section{Validity and reliability}

Study I was designed without plans for a follow-up study, which is why the two questionnaire survey studies (studies I and V) are cross-sectional instead of longitudinal studies. The questionnaire used in studies I and V has not undergone a formal validation process, although the questionnaire was developed in a meticulous 6-month process to ascertain validity and reliability. The questionnaires were partially built on questions from former studies (Blendon et al. 2002; Pukk-Härenstam et al. 2009; Gaal et al. 2011). The content, structure and the wording of all questions in the questionnaire were scrutinized by several experts in different fields (but all associated with patient safety).

The response rates to the questionnaires were quite high (79\% in 2011 and $70 \%$ in 2014), and we were able to reach the targeted study populations in both studies. However, there could be some response bias because non-responders in survey research can be quite different from those who participate. It is also possible that social desirability bias may produce overly positive responses on patient safety. However, we asked for the respondents' perceptions and not their attitudes or opinions on patient safety issues.

Social desirability bias may also be relevant to the county councils' reporting in the patient safety reports. In study IV, all the information regarding 
the elements of structure, process and outcome was based on the published patient safety reports. No other sources were used to obtain further information. This means that there may exist elements in the county councils' patient safety work that are carried out but not reported. Confirmation bias may have led to more positive assessments of patient safety reports that were better written than others. However, this bias was hopefully mitigated by doing the inter-coder reliability checks. With some of the patient safety reports, it was very difficult to determine whether or not something had been implemented, or was planned to be implemented. The coding scheme used in study IV may be seen as a strength with regard to the validity and reliability of the analysis. The scheme and calculation framework underwent meticulous scrutiny and tested for inter-rater reliability, and improved over the years since 2011.

\section{Trustworthiness}

Lincoln and Guba's framework from 1985 is used to discuss the trustworthiness of the qualitative studies. The concept of trustworthiness of qualitative research concerns five aspects: credibility, dependability, confirmability, transferability and authenticity (Polit and Beck 2012; Shenton 2012).

The first criterion, credibility, is an overarching criterion, which refers to "confidence in the truth in the data and interpretations of them" (Polit and Beck 2012 p 585). There are two different aspects of credibility: how the study was conducted and how it was reported (Polit and Beck 2012). In retrospect, I believe that study II might have benefited from a different approach with Vincent's framework as the basis in the interview guide, or choosing only one of the levels in the framework to obtain an in-depth understanding. The decision to conduct interviews instead of undertaking a survey was based on the belief that the interviews would lead to a more in-depth understanding.

To address dependability (i.e. would the results be the same if the study was repeated), the operational processes in the study should be described in detail in the published paper so that a reader can judge whether the inquiry has been stable and consistent throughout the research process (Shenton 2012). The dependability has been assessed by scrutinizing and reflecting on the choices made throughout the research process with my supervisors. However, it is always a trade-off how much one can write re- 
garding the process, and hopefully it is described in sufficient detail in this thesis.

The selection of respondents for the interview study (II) may compromise bias, hence we asked patient safety officers to provide names; they may have chosen nurses with similar mindset and opinions as themselves. The selection of nurses may also compromise transferability, i.e. how well the reader can transfer the results to their own practice (Shenton 2012), because they work at the frontline level, but the questions and answers are at the organizational level, which may make it difficult to translate the suggestions for changes in practice.

For study III, this risk is considerably smaller because the interviewees were a homogeneous group with the same assigned work task (infection control practitioners assigned to manage the county councils' prevalence surveys of HAIs), representing all but three county councils. The interviewees all rated their knowledge of the county council's HAI surveillance as very good or excellent, and the data analysis confirmed that data saturation was reached after half of the completed interviews and most of the participants described the same obstacles, suggesting that the study gave a relevant picture of HAI surveillance in the county councils in Sweden.

Most of the interviews in study II and all of the interviews in study III were conducted over the telephone. Face-to-face interviews have the advantage of eliciting nonverbal information; telephone interviews allow the researcher to follow and respond to the interviewee through language and reflection, which has the potential of making the interviewee's descriptions richer (Irvine et al. 2013). Telephone interviews were practical as the participants were from different areas in Sweden and the interviews were conveniently fitted around the participants' busy work schedules; telephone interviews were also suitable for the descriptive aim of the study. Furthermore, research suggests that transcriptions of telephone and faceto-face interviews do not differ much (Sturges and Hanrahan 2014).

Another way of strengthening the credibility of the conduct of a study is to have a tactic to make the respondent answer as truthfully as possible (Shenton 2012). This was done in the interviews (studies II and III) by opening the questions with: "there is no right or wrong", "I want your view on this", along with probes to discover inaccurate or untruthful answers. Even though this was done at the interviews, participation in the studies (II and III) was voluntary, and their answers may differ from the broader population of nurses or other health care staff. 
The multidisciplinary research team in the qualitative studies may also be considered a strength under the credibility criterion, permitting different perspectives on the issues under study, along with member checks of the transcribed material to compare and develop the coding of the data. In study II, this multidisciplinary mix consisted of a nurse with clinical experience of patient safety (MR), an economist with implementation science and injury prevention research expertise (PN), a technical engineer with expertise in implementation science, innovation research and medical technology assessment. In study IV, further competence was added to the team with a physiotherapist researcher with implementation science expertise. 
Towards safer care in Sweden? 


\section{CONCLUSIONS}

The five studies of this thesis have sought to generate knowledge for improved understanding and explanation of influences on patient safety in county councils in Sweden. Taken together, the studies demonstrate that a broad range of factors are considered important in order to improve patient safety, implying that the county councils' efforts for safer care must be multifaceted and directed at multiple levels of health care. Infection control and learning from errors seem to be particularly important areas.

More specifically, the thesis supports a number of conclusions with regard to the findings of the different studies:

- Conditions for the county councils' patient safety work could be improved, according to the county councils' patient safety officers (i.e. people within the county councils who had a designated task involving patient safety issues, had knowledge/overview of the county council's patient safety work and had the ability to influence this work).

- Efforts to prevent HAIs and rational antibiotics utilization are important for improved patient safety according to patient safety officers and reported in the patient safety reports. However, many infection practitioners do not believe that point prevalence surveys are an optimal tool to achieve improvement and learning regarding these infections.

- The new Patient Safety Act is considered an important factor in reaching the current levels of patient safety in the county councils, according to the patient safety officers.

- Patient safety culture is an important contextual factor for improved patient safety, according to the patient safety officers, nurses and infection control practitioners. However, the measurement of this culture is not considered important for the current levels of patient safety in the county councils.

- Education in patient safety issues for health care professionals is considered important for improved patient safety by patient safety officers and nurses.

- Patient involvement is considered important for improved patient safety by safety officers and nurses. Despite this, patient safety officers believe patient complaints and reports are not systematically analysed or followed up. 
- Nurses perceive that facilitators and barriers for improved patient safety exist at several system levels.

- Nurses and infection control practitioners in the county councils consider more nurses to be important for improved patient safety, but many patient safety officers do not believe an increased number of nurses is important for safer care.

- The county councils that patient safety officers perceive to be more successful than other county councils with regard to patient safety are those that have leadership support for patient safety, a long-term commitment to patient safety and a well-organized patient safety work process.

- Patient safety reports are perceived by patient safety officers to be useful for providing structure for patient safety work in the county councils, strengthening the focus on patient safety issues and learning from the patient safety work that is undertaken in the count councils.

- The financial incentive plan has influenced the reporting of the county councils' patient safety work in the patient safety reports, but is not perceived by patient safety officers as important for the county councils' current levels of patient safety.

- The data and results from the surveillance of HAIs are questioned with regard to reliability and applicability according to the infection control practitioners. 


\section{IMPLICATIONS AND FUTURE RESE- $\mathrm{ARCH}$}

The five studies of this thesis demonstrate that patient safety truly is multifaceted. There is a plethora of influences on patient safety in the Swedish county councils according to those who have voiced their opinion in the studies. The studies show that much patient safety work is ongoing in the county councils, but it is also evident that much can be improved.

However, the thesis also suggests that there is insufficient translation of data and information into action and learning for improved patient safety. The reporting and analysis of risks and adverse events must be linked to appropriate actions and feedback on the outcomes of completed activities to generate the required learning to achieve improvements over time. The same case can be made for all the other measurements of the various patient safety-related outcomes, e.g. pressure ulcers, HAIs and patient safety culture. One of the studies highlighted scepticism regarding the measurement of HAI and the use of the results at the clinic level.

The clinics must feel ownership of the results and be responsible for taking appropriate actions. However, this decentralization means that if one clinic has developed effective solutions to address certain patient safety problems (i.e. risks and adverse events), this knowledge and experience might not have much impact beyond the specific clinic. Hence, there appears to be a trade-off between addressing patient safety problems close to their source, with learning being primarily individual and intradepartmental, and creating conditions that are conducive to interdepartmental organizational learning. Research is needed on how results from the many measurements (patient safety culture, HAIs, pressure ulcers, etc.) can be transferred back to the frontline personnel and the management level in order to generate learning. The nationally implemented Infection Tool and work by the STRAMA groups in the county councils have to be studied to understand how work on infection prevention and use of antibiotics can be improved.

Patient safety reports appear to be a useful tool for providing structure for patient safety work. Although the contents of these reports can be some- 
what sprawling, they are directed at a broad audience (including the public, stakeholders, politicians, health care staff and managers). In order to improve the quality and usefulness of the reports, they would benefit from using more tick box answers, supplemented with more descriptive texts for the interested reader. More detailed guidelines on the reporting would make the reports clearer and easier to digest. The reports could also be assembled using a web-based tool, for easier access to the reports and better presentations of the results, processes and structures for the county councils' patient work.

The financial incentive plan has ended (the last year to receive reimbursement was 2014), but it is important for further investigations of the impact of the plan. Financial incentives are known to have various effects on clinical decision making (Chaix-Couturier et al. 2000). Financial interests may trump other responsibilities or conflict with evidence. The consequences are sometimes limited continuity of care and underuse or delayed provision of certain services. What aspects of the patient safety work in the county councils were improved? Did other aspects not improve because the focus was on other structures and processes? How should a future plan be designed?

More research is needed to find strategies and practices for improved patient safety. Such strategies can be based on incentives as well as intrinsic motivation among health care professionals to deliver safe, effective and equitable care. 


\section{REFERENCES}

Agency for Healthcare Research \& Quality's (AHQR). (2013) Glossary.

[Webpage]. Accessed 2015-11-25 at:

http://psnet.ahrq.gov/glossary.aspx?indexLetter=P

Amalberti, R., Auroy, Y., Berwick, D. and Barach, P. (2005) Five system barriers to achieving ultrasafe health care. Annals of Internal Medicine, 142, 756764.

Anderson, O., Davis, R., Hanna, GB. and Vincent, CA. (2013) Surgical adverse events: a systematic review. American Journal of Surgery, 206, 253-262.

Argyris, C. (2004) Reasons and rationalizations: the limits to organizational knowledge. Oxford, New York: Oxford University Press.

Bååth, C., Idvall, E., Gunningberg, L. and Hommel, A. (2014). Pressurereducing interventions among persons with pressure ulcers: results from the first three national pressure ulcer prevalence surveys in Sweden. Journal of Evaluation in Clinical Practice, 20, 58-65.

Baker, G.R., Norton, P.G., Flintoft, V., Blais R, Brown A, Cox. J., et al. (2004) The Canadian Adverse Events Study: the incidence of adverse events among hospital patients in Canada. Canadian Medical Association Journal, 170, 1678-1686.

Battles, J.B. and Stevens, D.P. (2009) Adverse event reporting systems and safer healthcare. Quality \& Safety in Health Care, 18, 2.

Beatty, P. (2004) The dynamics of cognitive interviewing. In: Presser, P., Rothger, J.M., Couper, M.P., Lessler, J.T., Martin, E., Martin, J., et al. (Eds.), Methods for testing and evaluating survey questionnaires. Hoboken, NJ: John Wiley.

Benn, J., Koutantji, M., Wallace, L., Spurgeon, P., Rejman, M., Healey, A., et al. (2009) Feedback from incident reporting: information and action to improve patient safety. Quality \& Safety in Health Care, 18, 11-21.

Blendon, R.J., DesRoches, C.M., Brodie, M., Benson, J.M., Rosen, A.B., Schneider, E., et al. (2002) Views of practicing physicians and the public on medical errors. New England Journal of Medicine, 347, 1933-1940.

Bredesen, I.M., Bjøro, K., Gunningberg, L. and Hofoss, D. (2015) The prevalence, prevention and multilevel variance of pressure ulcers in Norwegian hospitals: a cross-sectional study. International Journal of Nursing Studies, 52, 149-156.

Brennan, T.A., Leape, L.L., Laird, N.M., Hebert, L., Localio, A.R., Lawthers, A.G., et al. (1991) Incidence of adverse events and negligence in hospitalized patients. Results of the Harvard Medical Practice Study I. New England Journal of Medicine, 324, 370-376. 
Byrd, J. and Thompson, L. (2008) "It's safe to ask": promoting patient safety through health literacy. Healthcare Quarterly, 11, 91-94.

Chaix-Couturier, C., Durand-Zaleski, I., Jolly, D. and Durieux, P. (200o) Effects of financial incentives on medical practice: results from a systematic review of the literature and methodological issues. International Journal of Quality Health Care, 12, 133-142.

Choi, M. and Ruona, W.E.A. (2011) Individual readiness for organizational change and its implications for human resource and organizational development. Human Resource Development Review, 10, 46-73.

Damschroeder, L.J., Aron, C.D., Keith, R.E., Kirsh, S.R., Alexander, J.A. and Lowery, J.C. (2009) Fostering implementation of health services research findings into practice: a consolidated framework for advancing implementation science. Implementation Science, 4, 50.

Davis, P., Lay-Lee, R., Briant, R., Ali, W., Scott, A. and Schug, S. (2002) Adverse events in New Zealand public hospitals I: occurrence and impact. New Zealand Medical Journal. 115, U271.

Davis, R.E., Sevdalis, N. and Vincent, C.A. (2011) Patient involvement in patient safety: how willing are patients to participate? BMJ Quality and Safety, 20, 108-114.

De Feijter, J.M., Grave, W.S., Muijtjens, A.M., Scherpbier, A.J.J.A. and Koopmans, R.P. (2012) A comprehensive overview of medical error in hospitals using incident-reporting systems, patient complaints and chart review of inpatient deaths. PLoS One, 7, e31125.

Deming, W.E. (1986) Out of the crisis. Cambridge, MA: MIT Press (reprinted in 2000).

Department of Health (2000). An organisation with a memory: report of an expert group on learning from adverse events in the NHS Chaired by the Chief Medical Officer. London: The Stationery Office.

Donabedian, A. (1966) Evaluating the quality of medical care. The Milbank Memorial Fund Quarterly, 44(3 Pt. 2), 166-203. Reprinted 2005 in The Milbank Quarterly, 83, 691-729.

Ellström, P.-E. (2010). Organizational Learning. In: B. McGaw, P. L. Peterson, \& E. Baker (Eds.) International Encyclopedia of Education, 3rd Edition. Amsterdam: Elsevier.

Emmerson, A.M., Enstone, J.E., Griffin, M., Kelsey, M.C. and Smyth, E.T. (1996) The second national prevalence survey of infection in hospitals overview of the results. Journal of Hospital Infection, 32, 175-190.

Eriksen, H.M., Iversen, B. and Aavitsland, P. (2005) Prevalence of nonsocomial infections in hospitals in Norway, 2002 and 2003. Journal of Hospital Infection, 60, 40-45.

Eriksen, H.M., Koch, A.M., Elstrøm, P., Nilsen, R.M., Harthug, S. and Aavitsland, P. (2007). Healthcare-associated infection among residents of long-term care facilities: a cohort and nested case-control study. Journal of Hospital Infection, 65, 334-340. 
Finch, R. (2012) Current challenges in antimicrobial resistance and healthcareassociated infections: role and organization of ARHAI. Journal of Antimicrobal Chemotherapy, 67(Suppl 1), 3-10.

Fournier, S., Brossier, F., Fortineau, N., Gillaizeau, F., Akpabie, A., Aubry, A., et al. (2012) Long-term control of vancomycin-resistant Enterococcus faecium at the scale of a large multihospital institution: a seven-year experience. Euro surveillance, 17, 20229.

Foy, R., Övretveit, J., Shekelle, P.G., Pronovost, P., Taylor, S.L., Hempel, S., et al. (2011) The role of theory in research to develop and evaluate the implementation of patient safety practices. BMJ Quality and Safety, 20, 453459.

Gaal, S., Verstappen, W. and Wensing, M. (2011) What do primary care physicians and researchers consider the most important patient safety improvement strategies? BMC Health Service Research, 11, 1.

Gallego, B., Westbrook, M.T., Dunn, A.G. and Braithwaite, J. (2012) Investigating patient safety culture across a health system: multilevel modelling of differences associated with service types and staff demographics. International Journal for Quality in Health Care, 24, 311-320.

Gandhi, T.K., Graydon-Baker, E., Huber, C.N., Whittemore, A.D. and Gustafson, M. (2005) Closing the loop: follow-up and feedback in the patient safety program. The Joint Commission Journal on Quality and Patient Safety, 31, 614-621.

Garside, P. (1999) The learning organization: a necessary setting for improving care? Quality in Health Care, 8, 211.

Ginsburg, L., Gilin, D., Tregunno, D., Norton, P.G., Flemons, W. and Fleming, M. (2009). Advancing measurement of patient safety culture. Health services research, 44, 205-224.

Goeschel, C.A., Wachter, R.M. and Pronovost, P.J. (2010) Responsibility for quality improvement and patient safety: hospital board and medical staff leadership challenges. Chest,138, 171-178.

Gorecki, C., Nixon, J., Lamping, D. L., Alavi, Y. and Brown, J. M. (2014). Patient-reported outcome measures for chronic wounds with particular reference to pressure ulcer research: A systematic review. International journal of nursing studies, 51, 157-165

Granberg, O. and Olsson, J. (2009) Från lärandets loopar till lärande organisationer. Lund: Studentlitteratur (in Swedish).

Gravel, D., Taylor, G., Ofner, M., Johnston, L., Loeb, M., Roth, V.R., et al.; Canadian Nosocomial Infection Surveillance Program, Matlow A. (2007) Point prevalence survey for healthcare-associated infections within Canadian adult acute-care hospitals. Journal of Hospital Infections, 66, 243248.

Gray, A., Dryden, M. and Charos, A. (2012) Antibiotic management and early discharge from hospital: an economic analysis. Journal of Antimicrobal Chemotherapy. 67, 2297-2302. 
Greenfield, T. (2002) Research methods for postgraduates. 2nd ed. London; Arnold.

Griffin, F.A. (2007) 5 Million Lives Campaign. Reducing methicillin-resistant Staphylococcus aureus (MRSA) infections. The Joint Commission Journal on Quality and Patient Safety, 33, 726-731.

Grol, R., Bosch, M.C., Hulscher, M.E.J.L., Eccles, M.P. and Wensing, M. (2007) Planning and studying improvement in patient care: the use of theoretical perspectives. The Milbank Quarterly, 85, 93-138.

Grol, R., Wensing, M. and Eccles, M. (2005) Improving patient care: the implementation of change in clinical practice. London: Elsevier.

Guldenmund, F.W. (2000). The nature of safety culture: a review of theory and research. Safety science, 34, 215-257.

Gunnarsdotter, S. (2013) Sluta rapportera avvikelser [Stop reporting discrepancies]. Läkartidningen, 13-14, 670 (in Swedish).

Hajdu, A., Samodova, O.V., Carlsson, T.R., Voinova, L.V., Nazarenko, S.J., Tjurikov, A.V., et al. (2007) A point prevalence survey of hospital-acquired infections and antimicrobial use in a paediatric hospital in north-western Russia. Journal of Hospital Infections, 66, 378-384.

Hall, J., Peat, M., Birks, Y., Golder, S., Entwistle, V., Gilbody, S., et al. (2010) Effectiveness of interventions designed to promote patient involvement to enhance safety: a systematic review. Quality \& Safety in Health Care, 19, $1-7$.

Haynes, A.B., Weiser, T.G. and Berry, W.R. (2009) A surgical safety checklist to reduce morbidity and mortality in a global population. New England Journal of Medicine, 360, 491-499.

Hsieh, H.F.and Shannon, S.E.(2005) Three approaches to qualitative content analysis. Qualitative Health Research, 15, 1277-1288.

Humphreys, H., Newcombe, R.G., Enstone, J., Emmerson, A.M., Humphreys, H., Fitzpatrick, F., et al.; on behalf of the Hospital Infection Society Steering Group. (2008) Four country healthcare associated infection prevalence survey 2006: risk factor analysis. Journal of Hospital Infection, 69, 249257.

Irvine, A., Drew, P. and Sainsbury, R. (2013) 'Am I not answering your questions properly?' Clarification, adequacy and responsiveness in semistructured telephone and face-to-face interviews. Qualitative Research, 13, 87-106.

Izquierdo-Cubas, F., Zambrano, A., Frómeta, I., Gutiérrez, A., Bastanzuri, M., Guanche, H., et al. (2008) National prevalence of nosocomial infections. Cuba 2004. Journal of Hospital Infection, 68, 234-240.

Kim, D.H. (1993). The link between individual and organizational learning. Sloan Management Review Fall, 37-50.

Kohn, L.T., Corrigan, J. and Donaldson, M.S. (2000). To err is human: building a safer health system. Washington, DC: National Academy Press. 
Landrigan, C. P., Rothschild, J. M., Cronin, J. W., Kaushal, R., Burdick, E., Katz, J. T., et al. (2004). Effect of reducing interns' work hours on serious medical errors in intensive care units. New England Journal of Medicine, 351, 1838-1848.

Leape, L.L., Brennan, T.A., Laird, N., Lawthers, A.G., Localio, A.R., Barnes, B.A., et al. (1991) The nature of adverse events in hospitalized patients: results of the Harvard Medical Practice Study II. New England Journal of Medicine, 324, 377-384.

Leape, L. L. (2002, November). Reporting of adverse events. In New England Journal of Medicine.

Listyowardojo, T.A., Nap, R.E. and Johnson, A. ( 2012) Variations in hospital worker perceptions of safety culture. International Journal for Quality in Health Care, 24, 9-15.

Lizioli, A., Privitera, G., Alliata, E., Banfi, E. A., Boselli, L., Panceri, M. L., et al. (2003). Prevalence of nosocomial infections in Italy: result from the Lombardy survey in 2000. Journal of Hospital Infection, 54, 141-148.

Llata, E., Gaynes, R.P. and Fridkin, S. (2009) Measuring the scope and magnitude of hospital-associated infection in the United States: the value of prevalence surveys. Clinical Infectious Diseases, 48, 1434-1440.

Longtin, Y., Sax, H., Leape, L.L., Sheridan, S.E., Donaldson, L. and Pittet, D. (2010) Patient participation: current knowledge and applicability to patient safety. Mayo Clinic Proceedings, 85, 53-62.

Lyytikäinen, O., Kanerva, M., Agthe, N., Möttönen, T. and Ruutu, P.; the Finnish Prevalence Survey Study Group (2008) Healthcare-associated infections in Finnish acute care hospitals: a national prevalence survey, 2005. Journal of Hospital Infection, 69, 288-294.

Marshall, M.N. (1996) The key informant technique. Family Practice 13, 92-97.

McNulty, C.A., Cookson, B.D. and Lewis, M.A. (2012) Education of healthcare professionals and the public. Journal of Antimicrobal Chemotherapy, 67(Suppl 1), 11-18.

Melinder, K. (2000). In search of risk and safety cultures - empirical and theoretical considerations in the settings of northern and western Europe. Doctoral thesis. Karolinska Institutet, Stockholm.

Ministry of Health and Social Affairs and SALAR (2011) [The Patient Safety Initiative, 2011, Agreement Between the Government and SALAR for Improved Patient Safety]. Stockholm (in Swedish). Accessed 2015-11-26 at: http://www.regeringen.se/contentassets/2fo64c7fd8254d1984426egd76d aebda/godkannande-av-en-overenskommelse-om-forbattradpatientsakerhet-2012

Moro, M.L., Mongardi, M. and Marchi, M. (2007) Healthcare-related infections outside the hospital: a new frontier for infection control. New Microbiologica, 30, 350-354.

Nemeth, C., Wears, R., Woods, D., Hollnagel, E. and Cook, R. (2008). Minding the gaps: creating resilience in health care. In Henriksen, K., Battles, J.B., 
Keyes, M.A. and Grady, M.L. (Eds.) Advances in patient safety: new directions and alternative approaches. Vol. 3. Rockville, MD: Agency for Healthcare Research and Quality.

Nicklin, W. and McVeety, J.E. (2001). Canadian nurses' perceptions of patient safety in hospitals. Canadian Journal of Nursing Leadership, 15, 11-21.

Nilsen, P. (2015) Making sense of implementation theories, models and frameworks. Implementation Science, 10, 53.

Nilsen, P., Nygren, M., Öhrn, A. and Roback, K. (2012) [Patientsäkerhet svårt att uppnå, svårt att värdera: Landstingens patientsäkerhetsberättelser granskas och diskuteras]. Läkartidningen, 109, 1028-1031 (in Swedish).

Ödegård, S., ed. (2013) Patientsäkerhet: teori och praktik. Stockholm: Liber.

Övretveit, J., Shekelle, P.G., Dy, S.M., McDonald, K.M., Hempel, S., Pronovost, P., et al. (2011) How does context affect interventions to improve patient safety? An assessment of evidence from studies of five patient safety pratices and proposals for research. BMJ Quality \& Safety, 20, 604-610.

Olsen, S., Neale, G., Schwab, K., Psaila, B., Patel, T., Chapman, J.E., et al. (2007) Hospital staff should use more than one method to detect adverse events and potential adverse events: incident reporting, pharmacist surveillance and local real-time record review may all have place. Quality \& Safety in Health Care. 16, 40-44.

Patankar, M.S., Brown, J.P., Sabin, E.J. and Bigda-Peyton, T.G. (2012). Safety culture: building and sustaining a cultural change in aviation and healthcare. Farnham: Ashgate.

Patton, M.Q. (2002) Qualitative research and evaluation methods. 3rd ed. Thousand Oaks, CA: Sage.

Phillips, D.C. and Soltis, J.E.( 2004) Perspectives on learning. 4th ed. New York: Teachers College, Columbia University.

Pittet, D., Panesar, S.S., Wilson, K., Longtin, Y., Morris, T., Allan, V., et al. (2011) Involving the patient to ask about hospital hand hygiene: a National Patient Safety Agency feasibility study. Journal of Hospital Infections, 77, 299-303.

Pittet, D., Panesar, S.S., Wilson, K., Longtin, Y., Morris, T., Allan, V., et al. (2011) Involving the patient to ask about hospital hand hygiene: a National Patient Safety Agency feasibility study. Journal of Hospital Infection, 77, 299-303.

Polit, D.F. and Beck, C.T. (2012). Nursing research: generating and assessing evidence for nursing practice. 9th ed. Philadelphia: Wolters Kluwer Health/Lippincott Williams \& Wilkins.

Pronovost, P., Holzmueller, C.G., Needham, D.M., Sexton, B.J., Miller, M., Berenholtz, S., et al. (2006) How will we know patients are safer? An organization-wide approach to measuring and improving safety. Critical Care Medicine, 37, 1988-1995. 
Pukk-Härenstam, K., Elg, M., Svensson, C., Brommels, M. and Øvretveit, J. (2009) Patient safety as perceived by Swedish leaders. International Journal of Health Care Quality Assurance, 22, 168-182.

Reason, J. (2000). Human error: models and management. BMJ, 320, 768770.

Reason, J. (2004) Beyond the organisational accident: the need for "error wisdom" on the frontline. Quality \& Safety in Health Care, 13(Suppl II), ii28ii33.

Richardson, A. and Storr, J. (2010) Patient safety: a literature [corrected] review on the impact of nursing empowerment, leadership and collaboration. International Nursing Review. 57, 12-21.

Rollenhagen, C. (2013) Systemtänkande och säkerhet [Systems thinking and safety]. In Ödegård, S. (Ed.) Patientsäkerhet: teori och praktik. Stockholm: Liber, pp. 179-194 (in Swedish).

Rowley, L. (2007) The wisdom hierarchy: representations of the DIKW hierarchy. Journal of Information Science, 33, 163-180.

Russ, S.J., Sevdalis, N., Moorthy, K., Mayer, E.K., Rout, S., Caris, J., et al. (2015) A qualitative evaluation of the barriers and facilitators toward implementation of the WHO Surgical Safety Checklist across hospitals in England: lessons from the "Surgical Checklist Implementation Project". Annals of Surgery, 261, 81-91.

Sari, A.B.A., Sheldon, T.A., Cracknell, A. and Turnbull, A. (2007) Sensitivity of routine system for reporting patient safety incidents in an NHS hospital: retrospective patient case note review. BMJ, 334, 79.

Schildmeijer, K. (2013) Aspects of retrospective record review -a matter of patient safety. Doctoral dissertation. Department of Health and Caring Sciences, Linnaeus University, Kalmar.

Schiøler, T., Lipczak, H., Pedersen, B.L., Mogensen, T.S., Bech, K.B., Stockmarr, A., et al. (2001) [Incidence of adverse events in hospitals. A retrospective study of medical records]. Ugeskrift for Laeger, 163, 5370-5378.

Schreier, M. (2012) Qualitative content analysis in practice. London: Sage.

Scott, T., Mannion, R., Davies, H. and Marshall, M. (2003). The quantitative measurement of organizational culture in health care: a review of the available instruments. HSR: Health Services Research, 38, 923-945.

SFS (1982:763) [Health Care Act]. Stockholm: Ministry of Health and Social Affairs (in Swedish).

SFS (2010:659) [Patient safety law]. Stockholm: Committee of Health and Welfare (in Swedish).

Shekelle, P., Pronovost, P.J., Wachter, R.M., Taylor, S.L., Dy, S.M. and Foy, R. (2011) Advancing the science of patient safety. Annals of Internal Medicine, 154, 693-696. 
Shojania, K.G. (2010) The elephant of patient safety: what you see depends on how you look. The Joint Commission Journal on Quality and Patient Safety, 36, 399-401.

SOFS (2003:460) Lag om etikprövning av forskning som avser människor. [Law regulating ethical approval for research concerning humans.] Stockholm: Utbildningsdepartementet (in Swedish).

Soop, M., Fryksmark, U., Köster, M. and Haglund, B. (2009) The incidence of adverse events in Swedish hospitals: a retrospective medical record review study. International Journal for Quality in Health Care, 21, 285-291.

SOSFS (2005:12 (M)) Ledningssystem för kvalitet och patientsäkerhet i hälsooch sjukvården. Stockholm: Socialstyrelsen [National Board of Health and Welfare].

SOU (2008:117) Patientsäkerhet. Vad har gjorts? Vad behöver göras? Stockholm: Fritzes Offentliga Publikationer.

Stavropoulou, C., Doherty, C. and Tosey, P. (2015) How Effective Are IncidentReporting Systems for Improving Patient Safety? A Systematic Literature Review. Milbank Quarterly, 93, 826-866.

Sturges, J.E. and Hanrahan, K.J. (2004) Comparing telephone and face-to-face qualitative interviewing: a research note. Qualitative Research, 4, 107118.

Swedish National Audit Office (2015) Patientsäkerhet- har staten gett tillräckliga förutsättningar för en hög patientsäkerhet? rir 2015:12. Riksdagens tryckeri: Stockholm

Taylor, S.L., Dy, S., Foy, R., Hempel, S., McDonald, K.M., Övretveit, J., et al. (2011) What context features might be important determinants of the effectiveness of patient safety practice interventions? BMJ Quality \& Safety, 20, 611-617.

The Joint Commission (2012) Safe surgery checklist. Accessed 2016-01-30 at: http://www.jointcommission.org/safe surgery checklist/

Thomas, E.J. and Petersen, L.A. (2003) Measuring errors and adverse events in health care. Journal of General Internal Medicine, 18, 61-67.

Thor, J. (2007) Getting going on getting better: how is systematic quality improvement established in a healthcare organization. Doctoral dissertation. Karolinska Institutet, Stockholm.

Van Beuzekom, M., Boer, F., Akerboom, S. and Dahan, A. (2013) Perception of patient safety differs by clinical area and discipline. British Journal of Anaesthesia, 110, 107-114.

Van der Kooi, T.I., Manniën, J., Wille, J.C. and van Benthem, B.H. (2010) Prevalence of nosocomial infections in The Netherlands, 2007-2008: results of the first four national studies. Journal of Hospital Infection, 7, 168-172.

Vanderwee, K., Clark, M., Dealey, C., Gunningberg, L. and Defloor, T. (2007) Pressure ulcer prevalence in Europe: a pilot study. Journal of Evaluation in Clinical Practice, 13, 227-235. 
Vincent, C. (2007) Incidence reporting and patient safety. Emphasis is needed on measurement and safety improvement programmes. $B M J, 334,51-56$.

Vincent, C. (2010) Patient safety. John Wiley \& Sons.

Vincent, C., Taylor-Adams, S. and Stanhope, N. (1998) Framework for analysing risk and safety in clinical medicine. $B M J, 316,1154-1157$.

Wallace, L., Spurgeon, P., Benn, J., Koutantji, M. and Vincent, C. (2009) Improving patient safety incident reporting systems by focusing upon feedback - lessons from English and Welsh trusts. Health Services Management Research, 22, 129-135.

Walshe, K. and Boaden R (Eds.) (2006). Patient safety: research into practice. New York: McGraw-Hill Medical.

Ward, J.K., McEachan, R.R., Lawton, R., Armitage, G., Watt, I. and Wright, J. (2011) Patient involvement in patient safety: protocol for developing an intervention using patient reports of organisational safety and patient incident reporting. BMC Health Service Research, 11, 130.

Weaver, S.J., Lubomksi, L.H., Wilson, R.F., Pfoh, E.R., Martinez, K.A. and Dy, S.M. (2013). Promoting a culture of safety as a patient safety strategy: a systematic review. Annals of Internal Medicine, 158, 369-374.

Westbrooks, J.I., Li, L., Lehnbom, E.C., Baysari, M.T., Braithwaite, J., Burke, R., et al. (2015) What are incident reports telling us? A comparative study at two Australian hospitals of medication errors identified at audit, detected by staff and reported to an incident system. International Journal for Quality in Health Care, 27, 1-9.

Wilson, R.M., Runciman, W.B., Gibberd, R.W., Harrison, B.T., Newby, L. and Hamilton, J.D. (1995). The Quality in Australian Health Care Study. Medical Journal of Australia, 163, 458-471.

World Health Organization (2008) WHO guidelines for safe surgery 2009: safe surgery saves lives. Geneva: World Health Organization. Accessed 201601-31 at: http://apps.who.int/iris/bitstream/10665/44185/1/9789241598552 eng. pdf

World Health Organization (2011) Report on the burden of endemic health care-associated infection worldwide. Geneva: World Health Organization. Accessed 2016-01-22 at: http://apps.who.int/iris/bitstream/10665/80135/1/9'789241501507_eng. pdf?ua $=1$

World Health Organization (2013) Patient safety. Accessed 2015-11-25 at: http://www.euro.who.int/en/health-topics/Health-systems/patientsafety/patient-safety

World Health Organization (2014) Antimicrobial resistance: global report on surveillance 2014. Geneva, World Health Organization. Accessed 2014-1211 at:

http://www.who.int/drugresistance/documents/surveillancereport/en/ 
Yokoe, D.S., Anderson, D.J., Berenholtz, S.M., Calfee, D.P., Dubberke, E.R., Ellingson, K., et al. (2014) A compendium of strategies to prevent healthcare-associated infections in acute care hospitals: 2014 updates. American Journal of Infection Control, 42, 820-828.

Zwicker, D. and Fulmer, T. (2012) Reducing adverse drug events. In: Boltz, M., Capezuti, E., Fulmer, T. and Zwicker, D. (Eds.) Evidence-based geriatric nursing protocols for best practice. 4th ed. New York: Springer, pp. 324362. Accessed 2016-01-31 at: https://www.guideline.gov/content.aspx?id=43938 


\section{APPENDICES}

Appendix A: The national financial incentive plan for patient safety 20112014

Appendix B: Questionnaire, study I

Appendix C: Interview guide, study II

Appendix D: Interview guide, study III

Appendix E: Questionnaire, study IV and V 

Appendix A 




\begin{tabular}{|c|c|c|c|c|c|c|c|c|c|}
\hline 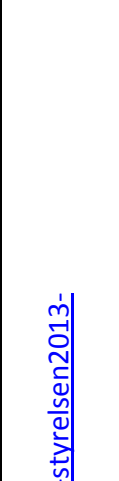 & & 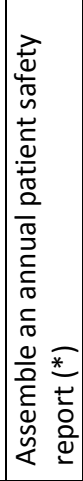 & 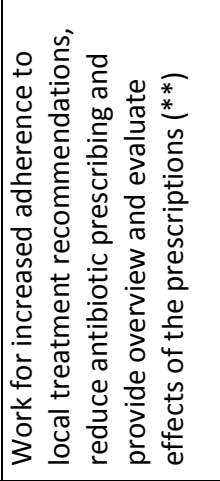 & 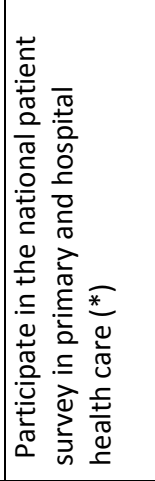 & 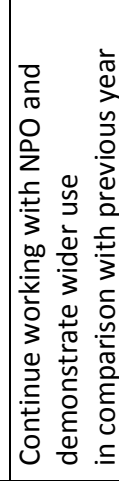 & 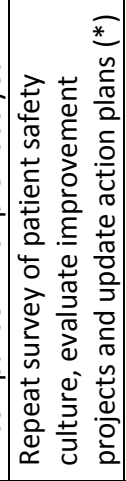 & 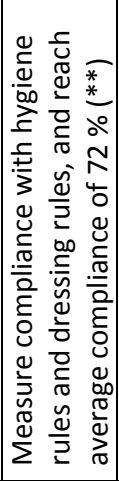 & 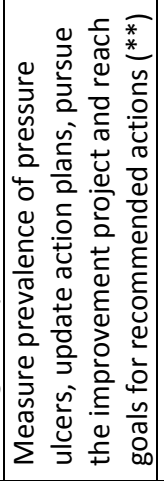 & 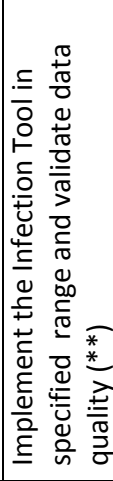 \\
\hline 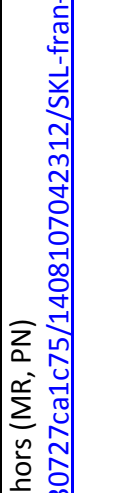 & $\begin{array}{l}m \\
\stackrel{D}{\mathcal{N}} \\
\end{array}$ & 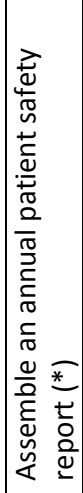 & 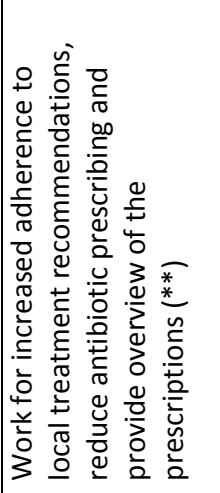 & 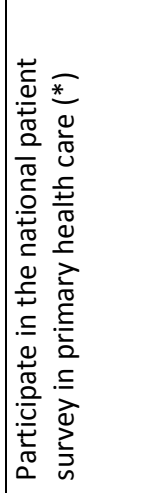 & 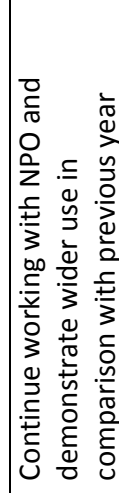 & 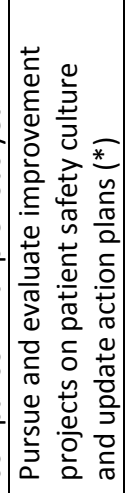 & 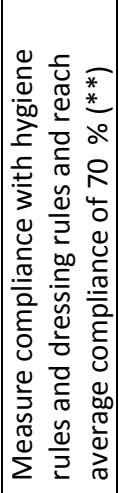 & 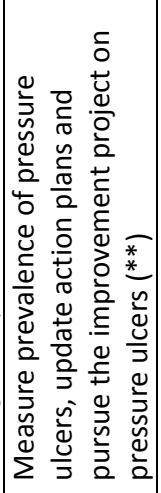 & 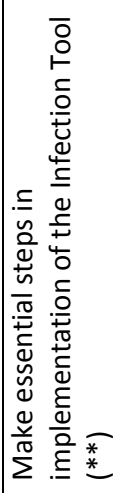 \\
\hline  & 궁 & 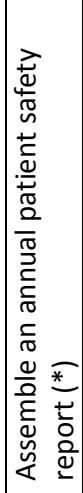 & 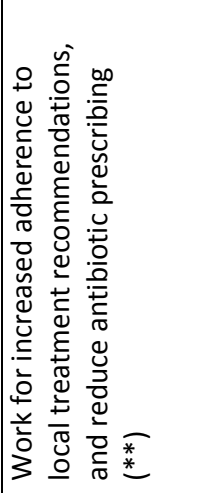 & 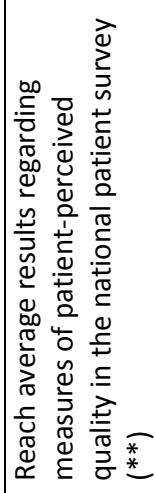 & 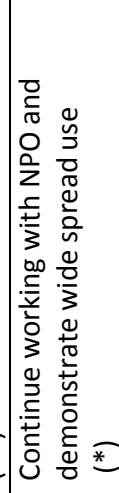 & 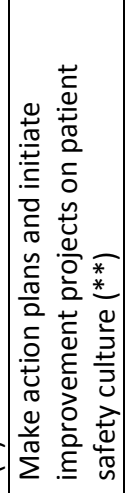 & 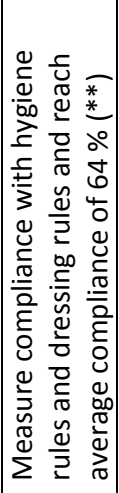 & 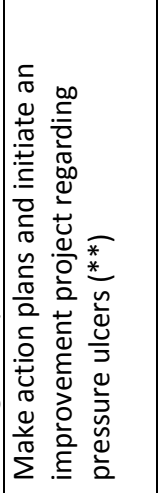 & 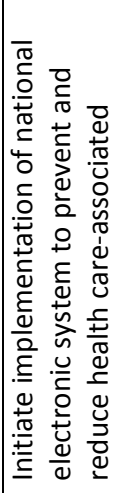 \\
\hline 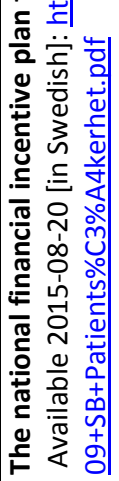 & ర్ & 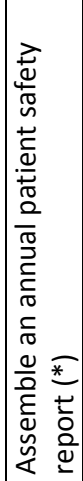 &  & 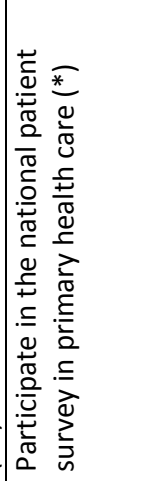 &  & 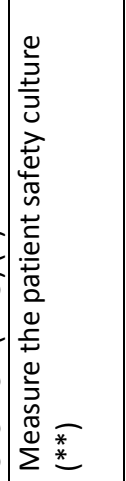 & 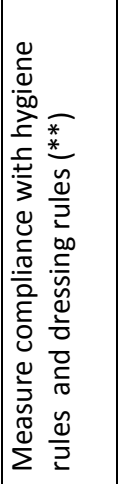 & 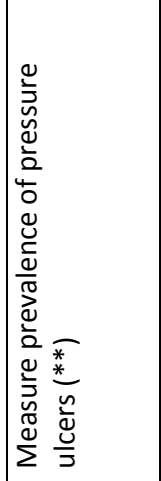 & \\
\hline
\end{tabular}




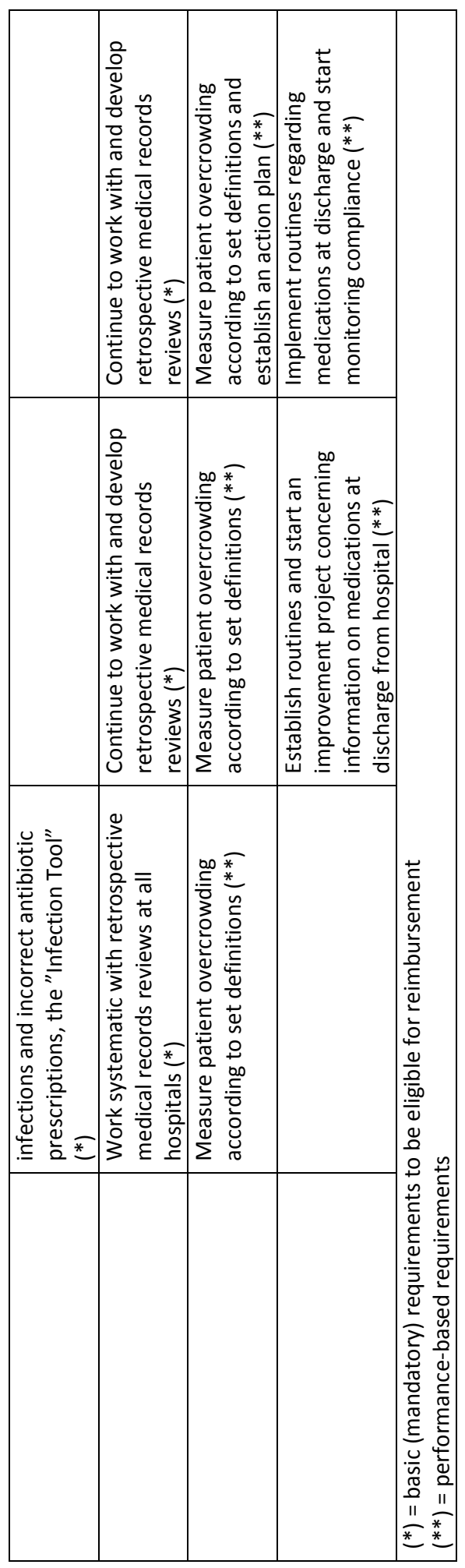



Appendix 



\section{Enkät om \\ landstingens/regionernas patientsäkerhetsarbete}

24 oktober 2011

Denna enkät vänder sig till patientsäkerhetsexperter inom varje landsting/region, dvs. personer som är insatta i och har kunskap om patientsäkerhetsarbetet som bedrivs i landstinget/regionen ifråga, samt på olika sätt har möjligheter att påverka detta arbete.

Vi är tacksamma om du tar dig tid att besvara frågorna så noggrant som möjligt. Du svarar anonymt. Svaren kommer endast att redovisas på aggregerad nivå.

Vi ber dig skicka tillbaka den ifyllda enkäten i det portofria svarskuvertet när du är färdig.

Vi som genomför studien är Mikaela Nygren, Per Nilsen och Kerstin Roback vid Linköpings universitet i samverkan med Annica Öhrn och Hans Rutberg vid Landstinget i Östergötland och Linköpings universitet. Studien bedrivs i samarbete med Sveriges Kommuner och Landsting (SKL), vars projektledare är Eva Estling. Kontakta oss gärna om du har frågor eller vill veta mer om undersökningen:

Mikaela Nygren

Telefon: 010-103 4980

E-mail: Mikaela.nygren@liu.se

Per Nilsen

E-mail: Per.nilsen@liu.se

Kerstin Roback

E-mail: Kerstin.roback@liu.se

Ett stort tack på förhand för din medverkan! 


\section{A. Bakgrundsuppgifter}

1 Vad är din nuvarande position/titel (fler än ett kryss är möjligt):

\begin{tabular}{ll}
$\square$ & Chefläkare \\
\hline$\square$ & Läkare \\
\hline$\square$ & Hygienläkare \\
\hline$\square$ & Chefsjuksköterska \\
\hline$\square$ & Sjuksköterska \\
\hline$\square$ & Undersköterska \\
\hline$\square$ & Hygiensköterska \\
\hline$\square$ & Verksamhetsutvecklare \\
\hline$\square$ & Vårdutvecklare \\
\hline$\square$ & Administrativ personal \\
\hline$\square$ & Annat:
\end{tabular}

2 Hur länge har du haft ett uppdrag att arbeta med patientsäkerhetsfrågor i landstinget/regionen?
$\square<1$ år
$\square 1-2$ år
$\square 3-5$ år
$>5$ år

3 Hur pass god kunskap/översikt bedömer du att du har om landstingets/regionens patientsäkerhetsarbete?

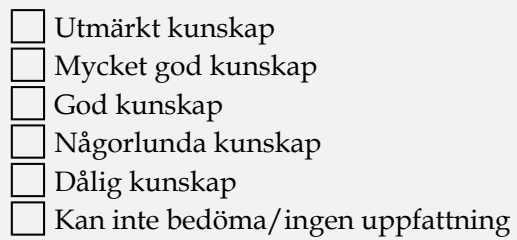

4 Vilka möjligheter bedömer du att du har att påverka landstingets/regionens patientsäkerhetsarbete?
$\square$ Utmärkta möjligheter att påverka
Mycket goda möjligheter att påverka
$\square$ Goda möjligheter att påverka
$\square$ Någorlunda möjligheter att påverka
$\square$ Dåliga möjligheter att påverka
$\square$ Kan inte bedöma/ingen uppfattning

5 Jämfört med 2008, anser du att patientsäkerheten i ert landsting/region är bättre eller sämre nu?




B. I vilken utsträckning anser du att följande påståenden stämmer för ert landsting/region?

\begin{tabular}{cc|c|cc}
$\begin{array}{c}\text { Stämmer } \\
\text { helt }\end{array}$ & $\begin{array}{c}\text { Stämmer } \\
\text { till } \\
\text { stor del }\end{array}$ & $\begin{array}{c}\text { Stämmer } \\
\text { till } \\
\text { liten del }\end{array}$ & $\begin{array}{c}\text { Stämmer } \\
\text { inte alls }\end{array}$ & $\begin{array}{c}\text { Vet ej/ } \\
\text { ingen upp- } \\
\text { fattning }\end{array}$ \\
\end{tabular}

1 Patientsäkerhetsarbetet har bra stöd från

landstingets/regionens ledning

Patientsäkerhetsarbetet har bra stöd från cheferna/ledningen för verksamheterna

Det finns en tillräcklig budget för patientsäkerhetsarbetet

Det finns god beredskap att anslå resurser av olika

4 slag (pengar, personal, etc.) för att uppnå ökad patientsäkerhet

Det ställs höga krav på utbildning specifikt inom

5 patientsäkerhet för de som har uppdrag på området

6 Landstinget/regionen har väl fungerande system/struktur för att analysera avvikelser

Landstinget/regionen har väl fungerande

7 system/struktur för att genomföra händelseanalyser

8 Landstinget/regionen har väl fungerande system/struktur för att genomföra riskanalyser

Det finns en bra organisation/struktur för patientsäkerhetsarbetet

Landstinget/regionen har väl fungerande forum/möten för lärande kring patientsäkerhet

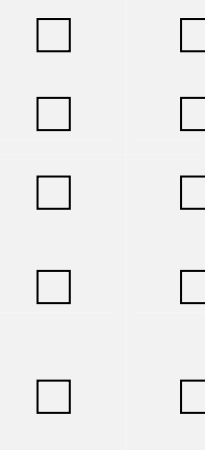

(1)
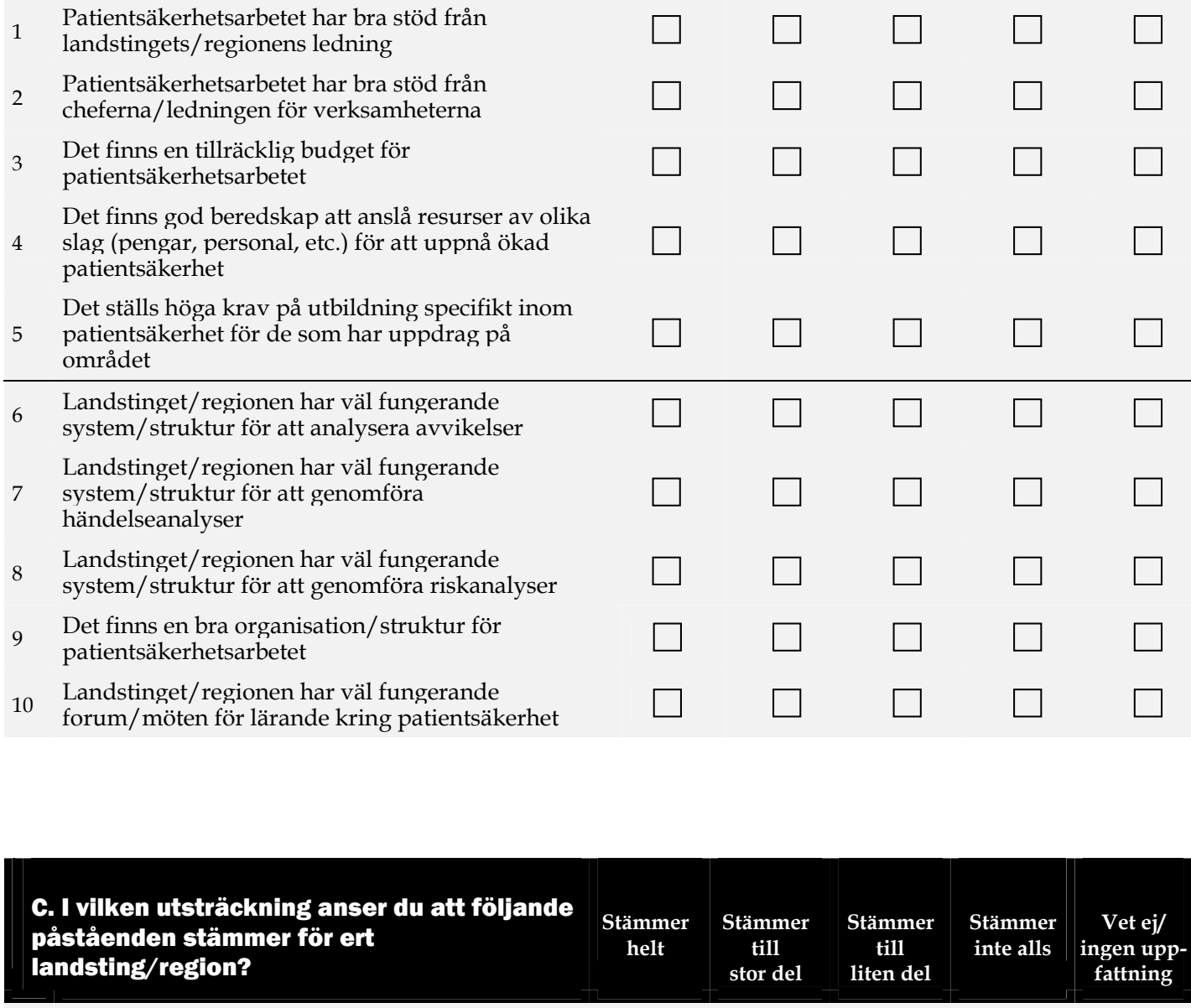

Uppgifter om avvikelser och risker sprids

1 systematiskt till medarbetare inom hela landstinget/regionen

Identifierade avvikelser och risker leder vanligen

2 till att åtgärder för förbättrad patientsäkerhet genomförs

3 De åtgärder som genomförs för förbättrad patientsäkerhet följs systematiskt upp

4 För lite tid och/eller resurser avsätts för att analysera avvikelser/risker

5 För lite tid och/eller resurser avsätts för att vidta förebyggande åtgärder

6 Händelse- och riskanalyser och andra analysmetoder leder till att rutiner och praxis förändras

7 Klagomål och anmälningar från patienter analyseras och följs upp systematiskt

Patienternas delaktighet är viktig för patientsäkerheten 


\section{Hur viktiga anser du att följande $\mathbf{3 6}$ faktorer har}

varit för att uppnå dagens nivå av patientsäkerhet i landstinget/regionen?

\begin{tabular}{c|cc||cc}
$\begin{array}{c}\text { Mycket } \\
\text { viktigt }\end{array}$ & $\begin{array}{c}\text { Ganska } \\
\text { viktigt }\end{array}$ & $\begin{array}{c}\text { Inte } \\
\text { särkilt } \\
\text { viktigt }\end{array}$ & $\begin{array}{c}\text { Inte alls } \\
\text { viktigt }\end{array}$ & $\begin{array}{c}\text { Ingen } \\
\text { upp- } \\
\text { fattning }\end{array}$
\end{tabular}

1 Genomförande av händelse- och riskanalyser

2 Rapportering och analys av avvikelser och risker

3 Strukturerad journalgranskning

4 Interna diskussioner med landstings-/regionledning, verksamhetschefer, vårdpersonal m.fl.

5 Externa diskussioner med andra som arbetar med patientsäkerhet

6 Uppgifter från kvalitetsregister

7 Forskning och vetenskapliga artiklar om patientsäkerhet

8 Lex Maria-beslut

9 Klagomål och anmälningar från patienter

10 Informationsmaterial och utskick från LÖF (Landstingens Ömsesidiga Försäkringsbolag)

11 Föreskriften SOSFS 2005:12, ledningssystem för kvalitet och patientsäkerhet i vården samt handboken God Vård

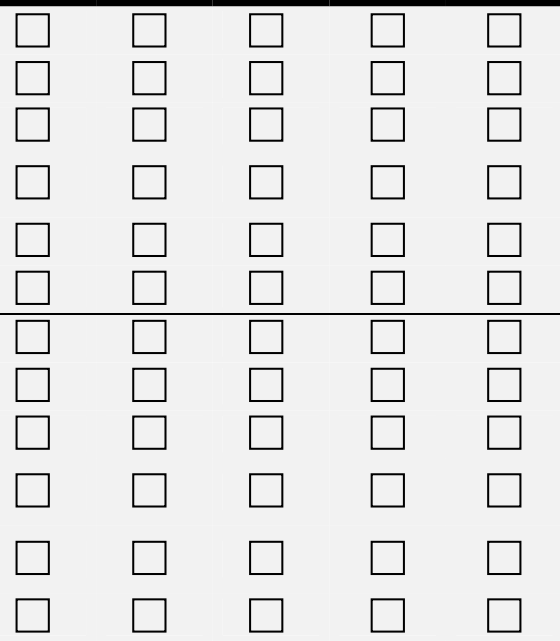

12 Den nya patientsäkerhetslagen (SFS 2010:659)

13 Upprättande av patientsäkerhetsberättelse (grundläggande krav för prestationsbaserad ersättning (PBE))

14 Lokal STRAMA-grupp (grundläggande krav för PBE)

15 Medverkan i den nationella patientenkäten för primärvården (grundläggande krav för PBE)

16 Strukturella förutsättningar för implementering av Nationell Patient Översikt (grundläggande krav för PBE)

17 Patientsäkerhetskulturmätningar

18 Punktprevalensmätningar (PPM) av följsamhet till hygienregler

19 Trycksårsmätningar

20 Arbete/åtgärder för minskad antibiotikaförskrivning

21 Medverkan i SKL:s PPM av vårdrelaterade infektioner

22 Medverkan i SKL:s PPM av trycksår

23 Medverkan i SKL:s PPM av följsamhet till hygienregler

24 Användning av SKL:s åtgärdspaket: läkemedelsrelaterade problem

25 Användning av SKL:s åtgärdspaket: trycksår

26 Användning av SKL:s åtgärdspaket: undernäring

27 Användning av SKL:s åtgärdspaket: fall och fallskador

28 Användning av SKL:s åtgärdspaket: läkemedelsfel i vårdens övergångar

29 Användning av SKL:s åtgärdspaket: postoperativa sårinfektioner

30 Användning av SKL:s åtgärdspaket: infektioner vid centrala venösa infarter

31 Användning av SKL:s åtgärdspaket: vårdrelaterade urinvägsinfektioner

32 Användning av Handbok för patientsäkerhetsarbete: Att mäta patientsäkerhetskulturen

33 Användning av Handbok för patientsäkerhetsarbete: Riskanalys $\mathcal{E}$ händelseanalys

34 Användning av Strukturerad journalgranskning för att identifiera och mäta förekomst av skador $i$ vården enligt Global Trigger Tool

35 Användning av Säkrare vård och omsorg

36 Användning av checklista för säker kirurgi 


\section{E. Utifrån dagens nivå av patientsäkerhet i landstinget/regionen, hur viktiga anser du att följande 22 faktorer skulle vara för att uppnå ökad patientsäkerhet?

\begin{tabular}{cc|ccc}
$\begin{array}{c}\text { Mycket } \\
\text { viktigt }\end{array}$ & $\begin{array}{c}\text { Ganska } \\
\text { viktigt }\end{array}$ & $\begin{array}{c}\text { Inte } \\
\text { särskilt } \\
\text { viktigt }\end{array}$ & $\begin{array}{c}\text { Inte alls } \\
\text { viktigt }\end{array}$ & $\begin{array}{c}\text { Kan ej } \\
\text { förbättras } \\
\text { ytterligare }\end{array}$ \\
& & &
\end{tabular}

1 En förbättrad organisationskultur som uppmuntrar rapportering och undviker skuldbeläggande

2 Bättre kommunikation mellan vårdpersonal

Bättre kommunikation mellan vårdpersonal och patienter

4 Utökad utbildning/träning i frågor kring patientsäkerhet för hälso- och sjukvårdspersonal

Införande av patientsäkerhetskunskap som ett

5 obligatoriskt inslag i grundutbildningar för hälsooch sjukvårdspersonal

6 Ökad standardisering/enhetliggörande av medicinskteknisk utrustning och produkter

7 Bättre instruktioner/utbildning avseende medicinskteknisk utrustning

8 Konfidentiell rapportering av negativa händelser och tillbud till en oberoende myndighet

9 Lindrigare påföljder för personal som gör misstag

10 Strängare påföljder för personal som gör misstag

11 Starkare styrning från högsta ledningen

Förbättrad infektionskontroll, inklusive förbättrad handhygien

13 Ökad medverkan av farmaceuter, t.ex. vid sjukhusronder

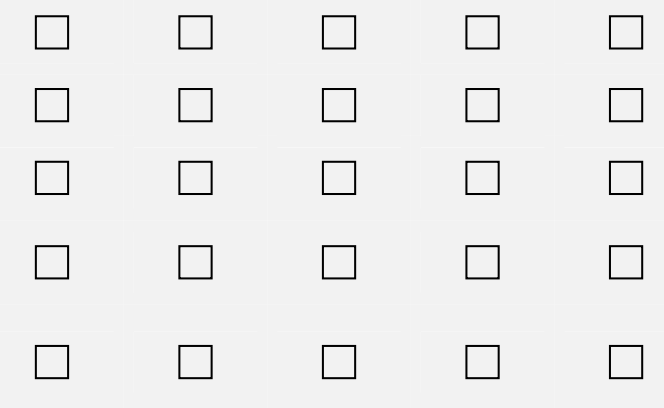

14 Reducerade arbetspass för läkare

15 Ökat antal läkare

16 Ökat antal sjuksköterskor

17 Bättre logistik gällande vårdplatser och överbeläggningar

18 Fler vårdplatser

19 Ökad samverkan med forskare

20 Ökade lagkrav på att genomföra aktiviteter och uppnå resultat beträffande patientsäkerhet

21 Fortsatt prestationsbaserad ersättning för genomförande av aktiviteter, uppnådda resultat, m.m.

22 Fler riktlinjer och rekommenderade åtgärder som vägledning för arbete med patientsäkerhet 


\section{Här finns möjlighet att komplettera svaren på D och E!}

Andra faktorer som har bidragit till att uppnå dagens nivå av patientsäkerhet i landstinget/regionen:

Andra förslag på förändringar för att uppnå ökad patientsäkerhet $i$ landstinget/regionen: 
Appendix C 

Table 1. Semi-structured Interview Guide with questions regarding processes, structure, facilitators and barriers to improve patient safety

\section{Background data}

Age

Profession

How long have you been in this occupation and in direct patient care

Do you have clearly stated Patient Safety responsibility in your employment?

\section{Factors for today's level of patient safety}

How do you work with patient safety work in your department/unit/clinic yourself?

How do you perceive the level of patient safety in your department/unit/clinic?

- Has it changed over the last three years?

Which factors do you see as most important for the level of patient safety today?

\section{Factors for future patient safety}

Which factors are important for improving patient safety in your department/unit/clinic?

Are there any obstacles to improve patient safety in your department/unit/clinic?

- What are the obstacles?

\section{Learning}

Incident reports - are they written?

- Are there any changes /improvements based on the incident reports?

- Are the incident report visible to everyone (health professionals) - how?

Root cause- and risk Analysis: Are you familiar with such an analysis method?

- What happened with the results from the Root cause- and/or risk analysis?

- Results distributed over the department/unit/clinic?

Is there learning in or from your patient safety work?

- By whom do you learn?

Over all, is there anything else you would like to add regarding factors for attaining current patient safety and/or for improving future patient safety? 

Appendix 



\section{Från siffror till handling - en studie om användning av resultat från PPM av VRI}

\section{Augusti 2012}

Ann-Christine Karell, Mikaela Nygren, Per Nilsen, Einar Sjölund \& Petra Hasselqvist

\section{Analysfas}

\section{Uppföljningsfas}

\section{Spridningsfas}

\section{Implementeringsfas}




\section{Introduktion}

Det här är de frågor som kommer att ställas under intervjun, du får gärna ta hjälp av andra för att få ett så utförligt svar som möjligt.

\section{Bakgrundsdata}

Vad är din nuvarande position/titel (fler än ett kryss är möjligt):

\begin{tabular}{|l}
$\square$ Chefläkare \\
\hline$\square$ Läkare \\
\hline$\square$ Hygienläkare \\
$\square$ Chefsjuksköterska \\
\hline$\square$ Sjuksköterska \\
\hline$\square$ Undersköterska \\
\hline$\square$ Hygiensköterska \\
$\square$ Verksamhetsutvecklare \\
\hline$\square$ Vårdutvecklare \\
\hline$\square$ Administrativ personal \\
\hline$\square$ Annat:
\end{tabular}

Hur länge har du haft ett uppdrag att arbeta med PPM av VRI i landstinget/regionen?

$\square<1$ år
$\square$ 1-2 år
$\square$ 3-5 år
$\square>5$ år

Hur pass god kunskap/översikt bedömer du att du har om landstingets/regionens PPM av VRIarbete?

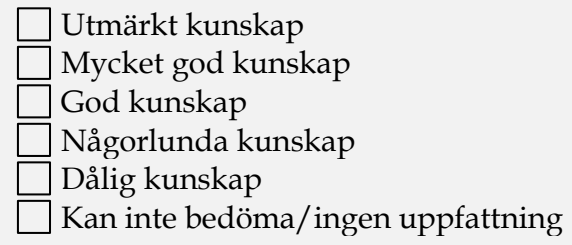

Beskrivkortfattat hur ansvaret är fördelat för PPM-VRI i ditt landsting/region: 


\section{Fas 1: Analysfas}

Analysfasen tänker vi oss tar vid när data från en PPM av VRI är insamlat: data finns nu $i$ en databas och behöver bearbetas, analyseras, tolkas, etc. för att kunna användas på olika sätt. $V i$ tänker oss att fasen leder fram till att data/resultat sammanställs på något sätt, i text, siffror, tabeller, etc. som redovisas i PM, rapporter, etc. - då tar nästa fas vid (se nedan)!

1. Hur jobbar ni med VRI-data?

- bearbetar, analyserar, tolkar, diskuterar?

- hur mycket tid uppskattar du att ni lägger ned, totalt sett, på analysfasen i ert landsting, t.ex. skattat i mantimmar, t.ex. totalt en manvecka?

2. Vilka är de största svårigheterna/hindren i analysfasen, som du ser det?

3. Kan du ge exempel på hur ni på ett bra sätt arbetat med analysfasen - goda exempel?

\section{Fas 2: Spridningsfas}

Spridningsfasen tar vid då data från en PPM av VRI på något sätt har "satts på pränt" $i$ text, siffror, tabeller, figurer, etc. så att de kan spridas/förmedlas till andra (förutom att de beskrivs muntligen).

1. Hur sprider ni resultat från en PPM av VRI internt?

- "vad" sprider ni, resultat i PM, rapporter, powerpoint-bilder, etc.?

- till vilka sprider/förmedlas detta?

- når informationen fram? tar man del av den?

- hur mycket sprids informellt, via samtal, möten, etc., jämfört med mer formell spridning vid planerade möten, rapporter, etc.?

2. Vilka är de största svårigheterna/hindren i spridningsfasen, som du ser det?

3. Kan du ge exempel på hur ni på ett bra sätt arbetat med spridningsfasen - goda exempel?

\section{Fas 3: Implementerings/åtgärdsfas}

Denna fas tänker vi oss att resultat från en PPM av VRI på något sätt används för att planera, bestämma och genomföra åtgärder för att förbättra VRI - resultat kopplas till faktiska insatser för sänkt VRI.

1. Hur används resultaten för att genomföra insatser för minskad VRI?

- vad är den viktigaste användning av resultaten?

- har ni ett system eller en struktur för att systematiskt omsätta VRI-resultat i handling eller sker detta arbete mer ad-hoc?

- finns nyckelpersoner (t.ex. enskilda personer som eldsjälar) som är viktiga för att omsätta resultat till handling?

2. Vilka är de största svårigheterna/hindren i implementeringsfasen, som du ser det? 
3. Kan du ge exempel på hur ni på ett bra sätt arbetat med implementeringsfasen goda exempel?

\section{Fas 4: Uppföljningsfas}

Denna fas handlar om uppföljning/utvärdering av åtgärder/insatser för sänkt VRI som bygger på resultat från PPM av VRI.

1. Hur utvärderar/följer ni upp insatser/åtgärder som ni har genomfört utifrån resultat från VRI-mätning?

- Exempel på åtgärder man har genomfört för minskad VRI där man har utgått från resultat som framkommit i PPM av VRI?

2. Vilka är de största svårigheterna/hindren i denna fas, som du ser det?

3. Kan du ge exempel på hur ni på ett bra sätt arbetat med uppföljningsfasen - goda exempel?

\section{Generella avslutningsfrågor}

Avslutningsvis några mer generella frågor!

1. Vad skulle du vilja förbättra för att reducera landstingets VRI?

- vad saknas? vad krävs?

- behövs mer data eller har ni tillräcklig kunskap om VRI-läget?

2. Vad är mest angeläget för att ert landsting ska bli bättre på att omsätta VRIresultat i handling?

- mer resurser i form av arbetstid eller kompetens? Andra resurser som det råder brist på?

3. Har ni några förbättringsförslag/önskemål till SKL's arbete med PPM av VRI? 


\section{Papers}

The articles associated with this thesis have been removed for copyright reasons. For more details about these see:

http://urn.kb.se/resolve?urn=urn:nbn:se:liu:diva-127307 